\title{
THE AFTERLIFE OF SAPPHO'S AFTERLIFE
}

\author{
Giovan Battista D’Alessio ${ }^{\star} \mid$ \\ University of Naples 'Federico II', Italy \\ ${ }^{\star}$ Corresponding author. Email: giovanbattista.dalessio@unina.it
}

This article explores an important aspect of the constellation of elements that contribute to the construction of the image of 'Sappho' from antiquity to the twentieth century, that of Sappho's ultimate destiny after her fatal leap from the Rock of Leucas. I first argue that the story of Sappho's leap lies behind the description of the Underworld in a long fragment of a fifth-century Attic comedy, the Miners of Pherecrates, and that indeed 'Sappho' appeared as a character in the play. The next sections examine the background and the iconic function of Sappho's leap in the underground Basilica near Porta Maggiore in Rome and connects all these elements to the way in which the Underworld is represented in Sappho's textual fragments. The fifth section of the article deals with the ways in which Sappho's fate was reconfigured from the Renaissance onward, examining first visual, musical and dramatic representations. In the final part I focus on the ways the motif is transformed by Baudelaire and Yourcenar. The image of the poetess can shift from being an icon of an eschatological message of new life to one of an exemplary failure, two poles that have an impact both on the reception of classical antiquity and on the vision of the destiny of poetry itself.

The complex constructions of the 'figure' of Sappho have enjoyed remarkable scholarly attention in recent years: this is due in part to the extraordinary capacity that Sappho's texts and her later recreations had to resonate within a lively and diverse reception, and, on the other hand, to an important increase of our knowledge of her texts, thanks to the publication of new papyrus fragments. And yet Sappho's 'constellation' ${ }^{\text {, }}$ remains as problematic and elusive as it is productive. To a degree even more marked than for most other archaic authors, we are faced with a strong divergence between the tradition that underlies the formation of a corpus of poems attributed to 'Sappho' - which finds a

\footnotetext{
${ }^{\mathrm{T}}$ I am very grateful to Serena Cannavale, Chris Carey, Roberta Denaro, Giulio Massimilla, Lorenzo Miletti, Cristina Pepe, Richard Rawles and to the readers for this journal for comments and criticism on various drafts, and to Dr Anna De Santis for providing new photographs of some details of the decoration of the Porta Maggiore Basilica.

I Used in a (vaguely) Benjaminian sense, for the historically varied reconfigurations of constant iconic and conceptual fragmentary elements; for the origin of the image in Benjamin and beyond see, for example, Krauß (20II); the chapter 'Unvorgesehene Konstellationen' in Mittelmeier (2013) (= Mittelmeier (2019) 55-62); Tagliacozzo (2018) 135-8.
} 
fundamental systematisation in the Alexandrian period in what we can define as the 'standard' edition - and the tradition of 'Sappho' as a cultural icon, which goes back to a very early period as witnessed by a surprisingly rich group of representations on vase paintings, starting from the late-sixth century. ${ }^{2}$ It would be a mistake to consider the latter simply a deformed reception of the 'scholarly' textual tradition, which in its turn is the result of a still largely obscure development. It is this second tradition, in fact, that has arguably had the stronger impact in Sappho's reception and for rather more than a millennium contributed to the construction of the various 'Sapphos' who have populated Western culture.

When, in I8I6, Friedrich G. Welcker published his little book on Sappho Rescued from a Dominant Prejudice, ${ }^{3}$ he had among his avowed purposes exactly that of clarifying the distinction between the two traditions, by applying the groundbreaking scholarly method of Quellenkritik of the new 'philology'. In this context Welcker attributed a fundamental role in the development of the Sapphic tradition to the deformations that her character suffered within Attic comedy. Since then comedy continues to occupy a conspicuous role within treatments of the figure of Sappho. And yet the evidence actually provided by extant comic texts is very exiguous indeed. With a single possible, rather evanescent, exception (Amipsias, with a play that could be dated in the late-fifth century), we are dealing with fourth-century texts, mainly attributable to Middle and New Comedy. ${ }^{4}$ Only for very few of these can we gather anything more than an extremely vague idea. This is the case with Antiphanes, where Sappho appears as the creator of riddles, and with Diphilus, where she is anachronistically wooed by Archilochus and Hipponax. It is possible that Sappho may have appeared in a fifth-century comedy of Cratinus (fr. $370 \mathrm{~K} .-\mathrm{A}$.) where an allusion is documented to Phaon, the mythical and elusive ferryman loved by Sappho in later traditions but never attested in actual Sapphic texts. ${ }^{5}$ Even in the case of Cratinus, however, where Phaon appears as loved by Aphrodite, as well as in the later Phaons of the comic poets Plato and Antiphanes, there is no evidence that Sappho was even mentioned, let alone that she appeared as a character. ${ }^{6}$

There is, however, an important piece of evidence for Sappho's presence in (or, at the very least, influence on) in a text belonging to the period of Old Comedy, to be dated possibly to the 420s, which seems to have escaped critical attention so far. If my argument is correct, this would allow us to reconstruct a key role for Sappho in a comedy with an eschatological focus, and to show how at this stage 'Sappho' had become part of

\footnotetext{
Cf. e.g. Yatromanolakis (2007) 5-164.

Welcker (I8I6).

We know of six comedies whose title was Sappho, by Amipsias, Ephippus, Amphis, Antiphanes, Timocles, Diphilus: cf. Brivitello (1998); Yatromanolakis (2007) 293-307; Neri in Neri and Cinti (2017) xciv-xcvi. For a possible appearance of Anacreon in Middle Comedy cf. Hutchinson (2020).

5 Cf. Olson and Seaberg (2018) I9I-2.

6 For Plato's Phaon cf. Pirrotta (2009) 338-74.
} 
a representation of the underworld for which we only have few and highly debated clues in her 'textual' tradition.

\section{The leap, and beyond}

We know rather little of Pherecrates' Miners. All we can say about its plot derives from its title and two textual fragments, even if one of them, with its thirty-three iambic trimeters, is in fact the longest verbatim quotation we have from its author. ${ }^{7}$ It is a detailed description of the Underworld as the Land of Cockaigne, where rivers flow rich in food, where roasted birds fly directly in people's mouths, where beautiful fruit grows by itself, and fragrant wines are served by girls blooming in their youth, wearing thin veils. This passage belongs within a chain of variations on a topos of Old Comedy documented by Athenaeus, within his survey, accompanied by ample quotations, in chronological order, of instances of the automatos bios $(6.267 \mathrm{e}-270 a) .{ }^{8}$ The sequence includes Cratinus' Ploutoi, Crates' Theria, Telecleides' Amphictyones, Pherecrates' Miners and Persians, and Aristophanes' Tagenistai (Roasters), with mentions of Nicophon's Sirens and of Metagenes' Thouriopersai. The evidence points to the conclusion that these comedies were all composed during the Peloponnesian War. In the case of the long quotation from the Miners a striking effect would have arguably been produced by the stark contrast between the idealised blessed life of the Underworld and the horrible, hellish working conditions of Laurion's silver mines, the most likely location for an Attic chorus of miners. A most peculiar element is provided by the interruption of this long description by a second character at lines $20-\mathrm{I}$ :

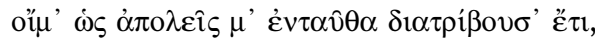

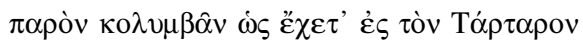

alas, woman, you'll kill me lingering still here while you can dive, just as you are, down into Tartarus.

This second character ('character B') expresses in a rather colourful way his or her impatience. From his/her words we understand that the dialogue takes place in the world of the living $(\dot{\varepsilon} v \tau \alpha \hat{v} \theta \alpha)$ and that the character who delivers the long description

7 The next section, on Pherecrates, expands, corrects and updates D'Alessio (2020). The attribution of the play was debated in antiquity: it was contested by Eratosthenes, who attributed it to a Nicomachus, perhaps on the basis of linguistic arguments (on the use of 'correct' Attic forms); other scholars, including possibly Aristophanes of Byzantium, offered counterarguments: cf. fr. II6 K.-A. and Tosi (1998) 328-31. For an ample survey of the critical positions on the comedy's date (roughly, and rather dubiously, situated between 427 and $4 \mathrm{I} 6$ ) and on the issue of its authenticity cf. Rehrenböck (1985) 125-9; Urios-Aparisi (1992) 320-321; Pellegrino (2000) 87 n. I; Franchini (2020) 98-Ioo, with rich bibliography (but no new arguments).

8 See, for example, Rehrenböck (1987); Ceccarelli (1996); Pellegrino (2000); Farioli (200I). More particularly, among the commentaries and more recent treatments on our two fragments, see Rehrenböck (1985) 132-76; Conti Bizzarro (I990-3) 9I-I2I; Urios-Aparisi (I992) 324-55; Pellegrino (2000) 85-I09; Farioli (200I) 9I-I04; Franchini (2020) 100-I6. 
('character A') is a woman (as implied by the feminine participle $\left(\delta 1 \alpha \tau \operatorname{li}^{\prime} \beta o v \sigma(\alpha)\right)$ who has come back from the Underworld, and whose leisurely description of its wonderful joys is contrasted by 'character B' with the possibility of 'diving into Tartarus' immediately. ${ }^{9}$ The identity of 'character A', who has experienced the pleasures of the Underworld, and who could dive into Tartarus, has remained so far an unsolved riddle. ${ }^{\text {IO }}$ There are, however, some important clues that can help us to get closer to the solution. In the first place, the image used to describe "character A"s potential access to Tartarus deserves particular attention. There is, in fact, a famous female character well known for her fatal leap into the sea, and to whom abundant, if controversial evidence, attributes a privileged position in the kingdom of the dead. One of my aims in this paper is to argue for the identification of 'character A' with Sappho (or, at least, for a very strong link between them).

The image of the dive into Tartarus, as noted by all commentators, evokes Anacreon's representation of his crazy dive from the Rock of Leucas $\left(376\right.$ PMG $=94$ Gentili, 23 Leo): ${ }^{\text {II }}$

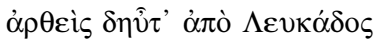

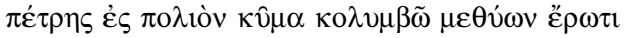 \\ Rising - look, once again - from the rock of Leucas \\ I dive into the grey sea, drunk with love.
}

The story of Sappho's leap from the Rock of Leucas is developed in full, among the sources available to us, in Sappho's Epistle to Phaon attributed to Ovid, ${ }^{\mathrm{I}}$ but is attested for the first time in Menander's Leucadia (fr. I Austin, Blanchard, 258 K.-T.), ${ }^{13}$ a passage quoted by Strabo (Io.2.9, 452c) as evidence that the poetess was the first one to threw herself from the promontory occupied by the famous temple of Apollo: ${ }^{14}$

9 The second person plural of the transmitted text implies that 'character A' is accompanied by one or more other individuals who could follow her in the Underworld (Rehrenböck (I985) I6r thinks that they might be the chorus of the Miners). On the various attempts to alter the text so as to understand a different subject by changing the verb to first person singular ( $\dot{\omega} \varsigma$ $\varepsilon \chi \omega$ ' $\varsigma$, Bothe, unlikely since the speaker is the one who criticises 'character A' for the

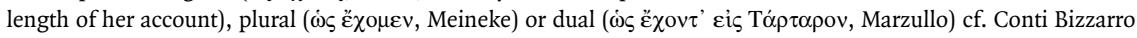
(1990-3) 98-9. I see no reason to tamper with the transmitted text.

Io For a survey of the attempts, vague and/or implausible (such as that of Edmonds, who identified the two characters with Persephone and Hermes, or that of Schmid, who relates 'character A' to the $\pi \varepsilon 1 \sigma 1 \theta$ óvator philosophers) cf. Rehrenböck (1985) I39-42; Pellegrino (2000) 88 n. 3; Franchini (2020) 96.

II This passage is alluded to, in a sympotic context, in Eur. Cycl. I64-6. Detailed commentary now in Bernsdorff (2020) 533-40 (Bernsdorff is in my opinion overcautious in doubting, at 537, that Anacreon's passage does indeed presuppose its previous appearance in connection to Sappho); for the sympotic context cf. Heinemann (2020) (in particular, on Anacreon and the Cyclops: 247).

I2 On this see D'Alessio (2018), with further bibliography. For a survey of the sources see Dörrie (1975) 33-49.

I3 For a recent survey of the evidence on the drama (with an appendix on some aspects of the reception of the motif in contemporary Greek literature) cf. Petrides (202I).

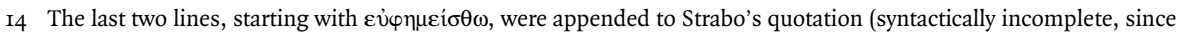
its last word in the transmitted text is $\dot{\alpha} \lambda \lambda \dot{\alpha}$ ), on the basis of a quotation in Hesychius, s.v. $\Lambda \varepsilon v \kappa \alpha \dot{\delta} \delta \mathrm{o}$, by R. Bentley, who made the hanging $\dot{\alpha} \lambda \lambda \dot{\alpha}$ at the end of Strabo's quotation the first word of the sentence continued in the fragment transmitted by Hesychius. This solution has been followed by most recent editors 


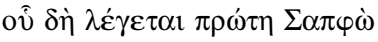

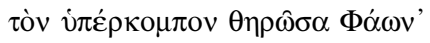

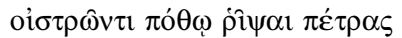

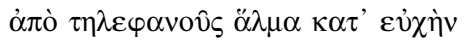

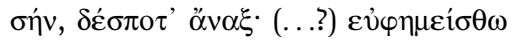

5

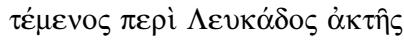

... where they say that Sappho, first,

in her hunt for haughty Phaon,

goaded by her desire, threw herself

from the far-seen rock in a leap, according to a vow

made to you, mighty Lord. (...?) Let the sanctuary

by Cape Leucas be praised. ${ }^{15}$

From what we know of the remnants of Menander's play, Sappho's story was not properly part of the plot, which, as usual in his comedies, dealt with contemporary events. It is clear that the story belonged to the traditional repertoire of tales on the poetess. Anacreon's image plays on the topical repetition ( $\delta \eta \hat{v} \tau \varepsilon$, 'look, once again') of a situation that is naturally extreme, and, one can imagine, hardly likely to be repeated. ${ }^{16}$ The usual and very reasonable assumption is that Anacreon's image is inspired by the use of a similar image (a metaphor or a simile) already in Sappho that would be at the origin of the biographical tradition, ${ }^{17}$ one of the several tesserae of the complex and creative

but cannot be considered completely certain. An alternative adopted in the past, and, in my opinion possibly superior, is the very easy correction of $\dot{\alpha} \lambda \lambda \dot{\alpha}$ into $\ddot{\alpha} \lambda \mu \alpha$ (Wordsworth (I844) 36), connecting the problematic

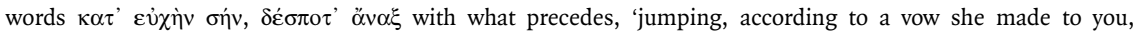
mighty Lord'. This would imply that Sappho's leap was linked to a vow to Apollo, as in Sappho's Epistle to Phaon, lines I8I-4 (cf. also Amores 2.I8.34, uotam) and would have the advantage of establishing a clear link between the Rock, the leap and the sanctuary of Apollo, which seems to be the focus of the fragment.

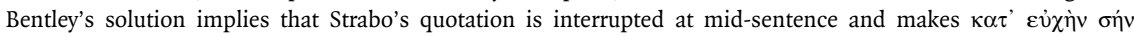

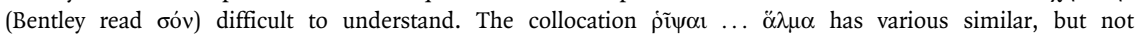
identical, parallels with analogous nouns and verbs in tragic diction, notably with verbs indicating 'falling' and

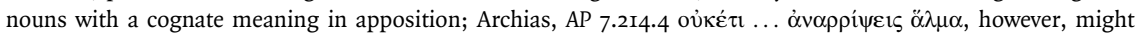
point to a different construction. Even in this case, anyway, it is likely that the fragment in Hesychius came from the same context as the one in Strabo, but we cannot be sure it followed immediately after it.

I5 Most editors understand $\pi \varepsilon \dot{\rho} \mathrm{\imath}$ in anastrophe (after Bernhardy): this, however, implies an impersonal use of the passive $\varepsilon \dot{\varphi} \varphi \eta \mu \varepsilon i ́ \sigma \theta \omega$, which seems at least very dubious. I switch back to the interpretation of $\pi \varepsilon \rho i$ governing the genitive in a local sense.

I6 But see the bizarre story of Ptolemy 'the Quail' in Phot. Bibl. 190.I53a.36-8 regarding one Makes from Bouthrotus who dived from the Rock four times to be delivered from the pains of love. The idea that in Anacreon $\delta \eta \hat{v} \tau \varepsilon$ should

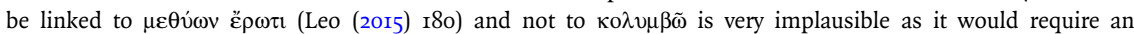
extremely convoluted sentence, and is not compatible with a natural word order and the poet's style. Anacreon's images for the onset of love, here as elsewhere, have the paradoxical quality of representing the repetition of unique imaginary experiences.

I7 Cf., for example, Wilamowitz-Moellendorff (1913) 3I; Nagy (1973) I42 (further bibliography in Brivitello (I998) 201 n. 56). The motif of the suicide for love from the Rock of Leucas must have had further lyric currency, given that Aristoxenus (fr. 89 Wehrli, in Ath. I4.6rgd-e) mentions a song sung by 'women of old times' that he attributes to 


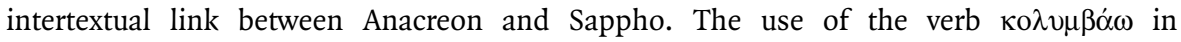
Pherecrates is also of some interest: it is rarely found in poetry and the passage in Anacreon is likely to be its earliest attestation (as a simple or compound verb) before the later-fifth century. ${ }^{18}$ It occurs also in the title of a mysterious work of Alcman, Ko $\lambda \nu \mu \beta \tilde{\omega} \sigma \alpha 1$, The Women Who Dive, which (according to a very dubious source) would have been found buried by the head of the otherwise unknown Tyronichos (Tynnichos?) of Chalcis. ${ }^{19}$ This too may point to an act of diving connected with radical changes of state, metaphorical or not. ${ }^{20}$ There are, however, serious doubts regarding the actual existence of such a work. ${ }^{21}$ The fact that in this title, too, we are dealing with female divers suggests, at any rate, that this might also be relevant to the constellation of passages we are examining here. ${ }^{22}$ And, of course, the piece of information about the funerary use of a roll with this work - be it real or fictional - does evoke interesting eschatological implications.

If this reconstruction of the play is correct, Pherecrates may be our earliest evidence for an evolution in the reception of Sappho which was eventually to give her story a special prominence in relation to ideas about the Underworld and more specifically about the fate of the soul after death, which will be the focus of the next section of this study. The leap into sea from the White Rock/ the Rock of Leucas indeed can be easily read as a metaphor of the passage to the afterlife. ${ }^{23}$ This is image has been detected, more or less

Stesichorus, on the love story of Euathlus and Calyce, which ends with the tragic dive of the heroine (277 PMGF = 326 Finglass; cf. Rutherford (2015), with bibliography).

I8 The nomen agentis occurs in Aesch. Suppl. 408 (in a simile concerning intellectual exploration). The compound form غ̇кко $\nu \mu \beta \alpha \dot{\alpha} \omega$, without metaphoric connotations, appears in Aristophanes' Babylonians (fr. 82 K.-A.), which might be more or less contemporary with the Miners, and, slightly later, in Euripides' Helen (l. 1609). Its first prose attestations start with Thucydides.

20 For a good critical survey of the dossier on this work see Ornaghi (2018), who conjectures that it dealt with a metaphoric dive, while leaving open the possibility that this was a later poem falsely attributed to Alcman.

2I Caution is in order especially because one of the two sources attesting the existence of the work is the summary of the Kavvi i $\sigma \tau o p i \alpha$, the New History, of the bizarre and largely untrustworthy Schwindelautor Ptolemy 'the Quail', preserved in codex I9o of Photius' Bibliotheca (I51a 4-20 Henry). Here the genitive of the name of the author of the work is transmitted as A A $\lambda \mu \alpha$ óvous: Meineke argued that this was a corrupt form not of the genitive of the

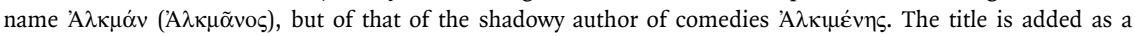
sort of afterthought to the six books of Songs in the entry on Alcman in the Byzantine encyclopaedia Suda, s.v. $\alpha$ I289 Adler. It is a well-known fact, though, that Suda made use also of the work of Ptolemy 'the Quail' (cf. Cameron (2004) I35 and I48, and sources nos. I9-23 in Pagani (2006); Pagani herself ignores the important contribution of Cameron (2004) and thus does not consider Ptolemy as a possible source of Suda), and it is readily conceivable that the addition of this title was due precisely to a redactor who had taken note of the passage in Ptolemy (if this is so, we would have only one source for the existence of this work, and a very suspicious one at that).

22 In general on the various metaphorical variations on the image of the leap into the sea (especially in relation to female characters) see Beaulieu (2016), above all ch. 5, 'Leaps of Faith? Diving into the Sea, Women and Metamorphosis', $145-66$, with rich bibliography.

23 In Sappho's biographical tradition the Rock of Leucas is identified with the cliff on the southern shore of the

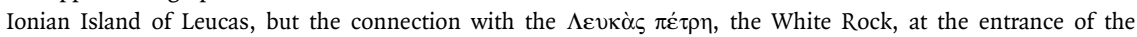
Underworld in Od. 24.II has often been made. For an early scholarly interpretation of the diving image as 
convincingly, also in funerary iconography starting from the late-sixth century: in the so called Tomb of Hunting and Fishing (Tarquinia, around 520 BCE), and, more convincingly, in the Tomb of the Diver (Paestum, around 500-475 BCE). ${ }^{24}$ In the case of the latter, the presence of a sympotic setting in other sections of the tomb has suggested the possibility that the dive might have been connected with mystery rites linked with the representation of the afterlife as involving the banquet of the blessed ones. ${ }^{25}$ Some scholars, on independent grounds, have argued that the description of the Underworld Land of Cockaigne in Pherecrates might also be read as a parody of such expectations, though this too remains uncertain. ${ }^{26}$

In any case, an eschatological reading of Sappho's leap is definitely attested some centuries later in the complex iconographic apparatus of one of the most impressive and enigmatic monuments of early Julio-Claudian Rome, the so-called Basilica near Porta Maggiore. This fascinating underground building was discovered by chance a little more than a century ago during repair works on the Rome-Cassino railway in 1917. It is dated to the late-first century $\mathrm{BCE}$ or the early-first century $\mathrm{CE}$ : it was built several metres below the level of the road in a zone of the city that hosted the funerary ground of the influential family of the Statilii Tauri and close to the horti Tauriani. The building, which has the structure of later basilicas, and in many respects anticipates features of the much later Christian 'churches', is richly decorated in various ways, most remarkably with stuccoes (originally partly painted), as part of an ambitious iconographic project. Following its discovery and publication it sparked a lively debate, especially among archaeologists and scholars of ancient religions. And while it continues to attract attention in these fields, it hardly features (beyond relatively few bare mentions in lists of images and footnotes) in the flourishing recent (and less recent) studies on Sappho's reception. ${ }^{27}$

related to the passage into a new life, based on literary attestations of the motif, see Dieterich (I893) 28 and already Kock (1862) go.

24 It is far from clear if the dive in the Tarquinia Tomb should be read as an eschatological symbol: cf. Hölscher (2020) 500-501; Ross Holloway (2006) 374-6 (though see still Cerchiai (2020)). On the Tomb of the Diver the debate is open: see at least Ross Holloway (2006), with bibliography, and most recently the essays in Meriani and Zuchtriegel (2020). Ampolo (1993) explored its similarities to an eschatological passage in Plutarch's De sera numinis uindicta (but this is based on the acceptance of a dubious conjecture of Pohlenz: see contra Taufer

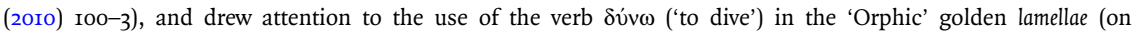
which see now also Bernabé (2020) 17-18). Bernabé (2020) connects the iconography of the Paestum tomb with Southern Italian 'Orphism' (cf. I4 n. I7, where, discussing previous bibliography, the author rules out the relevance of the case of Sappho on the basis of the later date of the Porta Maggiore Basilica, but does not explore the possibility of a much earlier tradition, though, of course, not necessarily within a 'Pythagorean' frame). For interpretations of the Tomb of the Diver that rule out an eschatological reading cf. at least Hölscher (2020) and Heinemann (2020) (among other contributions in Meriani and Zuchtriegel (2020)).

25 Cf. e.g. Bernabé (2020); contra Murray (2020), both with bibliography.

26 Rohde (1903) I.315 n. 2 notes: 'Anlass zu solchen Scherzen gab vermuthlich die orphische Verheissung eines

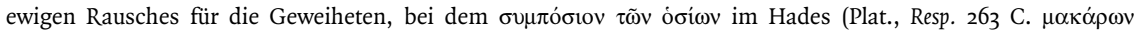

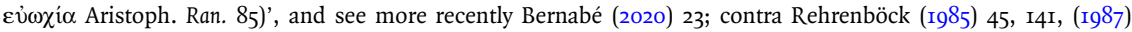
25. Conti Bizzarro (I990-3) 9I-2 points to some similarities to the section with the Myth of Er in Plato's Republic. The monument is not even mentioned in the recent Cambridge Companion on Sappho, Finglass and Kelly (202I). 
The interpretation of the building's general iconographic project is difficult. Some of the images seem to belong to an 'Orphic-Dionysiac' background; ${ }^{28}$ others are less clearly defined but do lend themselves to a reading as representations of (symbolic) death and new birth; others still feature scenes of life in the world of the living and - it has been argued - in the Underworld. The series includes mythical scenes such as the abduction of the Leucippids and of Ganymede, Pentheus torn apart by the Bacchae and the punishment of Marsyas. The most influential reading of the complex, which with some divergences of detail is still generally accepted by most scholars, is that developed by François Cumont and later by Jérôme Carcopino, who proposed a religious interpretation of the building as related to a mystery sect, even though their specific identification of this sect with the 'Neopythagoreans' has been variously qualified or rejected.

The topographic location of the building, near the cemetery of the gens Statilia and the horti Tauriani, is one of the grounds that have led to posit of a link with the family of the Statilii Tauri. Titus Statilius Taurius, consul in 26 and in 7 BCE, had been at the command of the land forces of Augustus' army at the battle of Actium. A few decades later, in $53 \mathrm{CE}$, under Claudius, his grandson, consul in $44 \mathrm{CE}$, was accused of being embroiled in magicae superstitiones (Tac. Ann. 12.59.2) and committed suicide before the process took place. The properties of the family seem to have been requisitioned by the state following his suicide (but the family did not suddenly disappear: his daughter, or niece, Statilia Messalina, was to become Nero's third wife). ${ }^{29}$

A key argument for the Neopythagorean hypothesis was provided by the impressive scene depicted in the Basilica's apse (Fig. I).

The scene represents on the right side a female character, holding with her right hand her veil filled by the wind and in her left hand a seven-stringed lyre, and stepping beyond the edge of a rocky cliff, accompanied, or pushed, by a little Eros. Before her is the sea, from which a muscular figure, apparently a Triton, ${ }^{30}$ emerges from the waist upward spreading a textile to welcome the arrival of the woman, the tip of whose right foot seems already

28 Entering into the debate of current scholarly definitions of 'Orphism' and its diachronic variants is out of the scope of this research; for two recent useful collections of papers exemplifying the different positions cf. Herrero de Jáuregui et al. (20II) and Edmonds (20II), and for a more recent 'revisionist' survey, Chrysanthou (2020).

29 This would chime well with the hypothesis that the underground Basilica was abandoned, pillaged and partly buried under its debris around that period: cf. e.g. Carcopino (I926) $55(=(2020) 62)$ and 6o-2 (= (2020) 66-7). Carcopino argues that the destruction took place before the decorations had been completed, but Bendinelli (I926) 844-5 seems to think that the spoliation of the building took place in late antiquity. See Sauron (I994) 606 n. 225 for a survey of the dates proposed for the building, and 6 13 for his proposal of a date under Augustus, attributing the initiative to the consul of 26 and 7 BCE.

30 Coarelli (I974) 2I5 suggests that this may be a female figure, Leucothea (see already Meautis (I930), contra Hubaux (I932) 387). Bendinelli (I926) cols. 649-50 n. 4 thinks that it must be a masculine figure, but recognises the affinity to female ones on Roman sarcophagi: 'a parte le forme massicce e muscolose del torso si preferirebbe vedere nella deità marina piuttosto una Tritonessa, la quale distenderebbe ad arco concavo, per l'occasione, quello stesso himation che vediamo così spesso tenuto aperto a vela come un nimbo intorno al campo, specialmente da divinità femminili marine, sopra sarcofagi e altri monumenti figurati ellenistico-romani'. After the most recent restoration it appears that the torso and the waist of this figure were covered with what look like shells (rather than clusters of seaweed). 


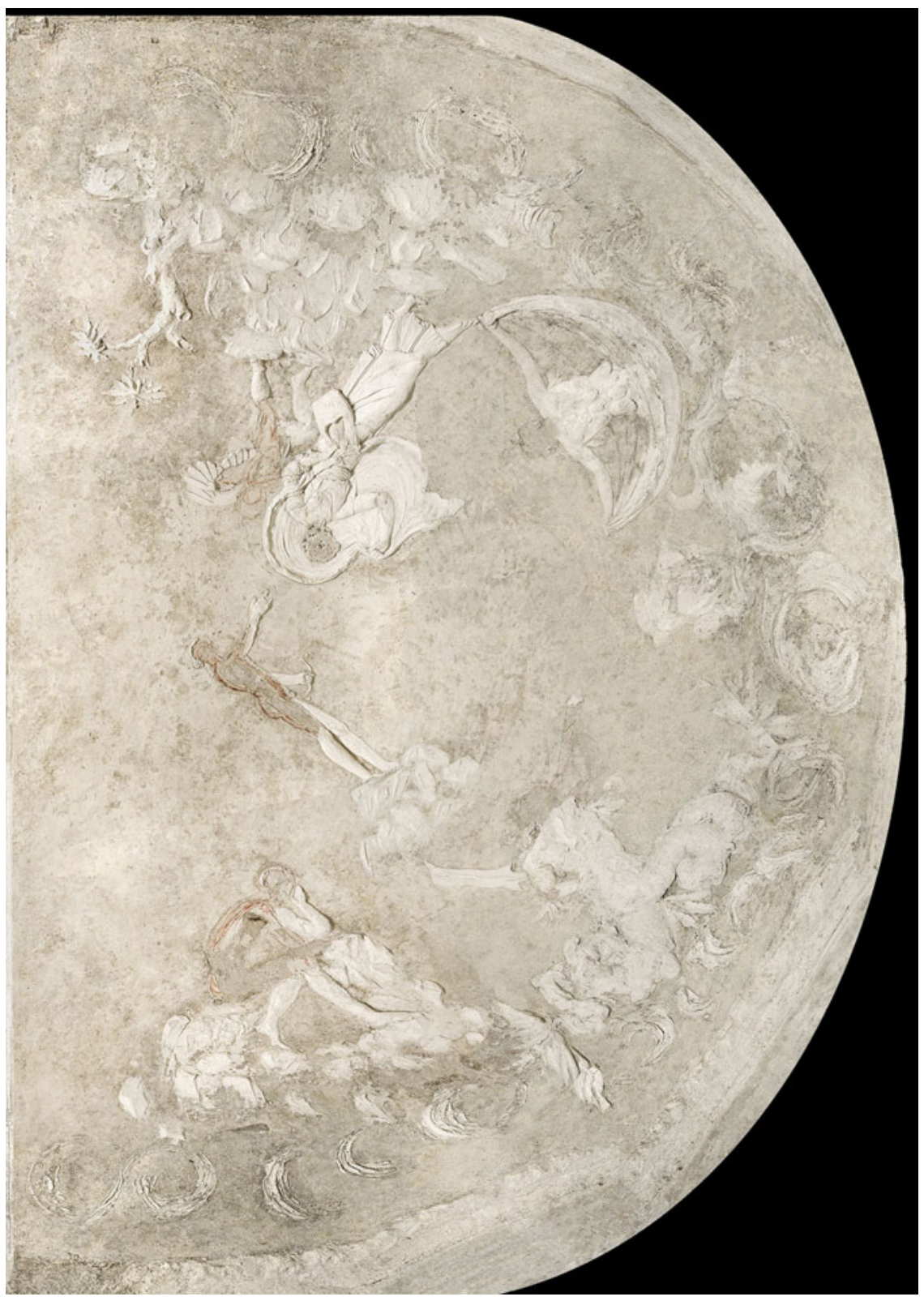

Figure I. The apse of the underground Basilica near Porta Maggiore after the most recent restoration. () Soprintendenza Speciale Archeologia Belle Arti e Paesaggio di Roma 
to touch his left hand. To his right a further marine figure might be another Triton, holding an oar and a trumpet. ${ }^{3 \mathrm{I}}$ Above him, on the summit of an isolated, higher, rock, Apollo faces towards the woman, holding a bow in his left hand, and stretching his right arm towards her. After a few uncertain attempts at making sense of it, the scene was brilliantly interpreted by Densmore Curtis in 1920 as a representation of Sappho's leap from the Leucadian Rock, in the presence of Apollo, the patron deity not only of the local temple but also of the nearby sanctuary of Actium (which is arguably important with regard to the possible role played by Titus Statilius Statius). ${ }^{32}$ After a few marginal hesitations, this interpretation has established itself, and is now generally accepted.

Carcopino found in this representation of Sappho's fatal leap an important clue for a 'Neopythagorean' reading of the Basilica, connecting the scene to Pliny, HN 22.20, a passage illustrating the magical properties of the eryngx or eryngium, a herb considered responsible for Sappho's falling in love with Phaon, and apparently much appreciated by Pythagoreans (test. 2Irb Voigt (only up to the word Sappho): portentosum est quod de ea [sc. erynge] traditur, radicem eius alterutrius sexus similitudinem referre, raro inuenta, set si uiris contigerit mas, amabiles fieri; ob hoc et Phaonem Lesbium dilectum a Sappho, multa circa hoc non Magorum solum uanitate, sed etiam Pythagoricorum). ${ }^{33}$ The connection in itself is far from cogent, as Pliny only implies that the Pythagoreans had something to say on the herb, but does not state that they mentioned it in connection to Sappho. Carcopino also pointed to the important role played by Nigidius Figulus in the formulation of 'Neopythagoreanism' in late Republican Rome, suggesting that his theories may have influenced the iconographic programme of the building. Some progress on this front was made by more recent scholars (especially Sauron (1994)), but a precise identification of the religious background of this extraordinary monument cannot be made with any certainty. It will probably be safer to define it as eclectic, or syncretistic. ${ }^{34}$ In any case, whatever label we wish to impose on these images, one can hardly doubt the central role of an allegorical/eschatological interpretation of Sappho's leap as representing the passage of the soul to a better life.

It is less certain how we should read the lower left portion of the decoration of the apse, representing a male figure wearing a short mantle, facing right, sitting on a rock by the sea in a pose of mourning (his cheek leaning on the palm of his hand). His interpretation as a repentant Phaon has no support in extant texts. M. Detienne (I958) read the figure as Odysseus on the island of Calypso, proposing a link to a Neoplatonic allegorical reading of the episode. More recently an identification with Philoctetes has been proposed (Cruciani (2000)). None of these seems compelling, but Detienne's remains in my opinion the most attractive.

3I Cf. Carcopino (I926), in particular 37I-83 (= (2020) 248-56); Dörrie (I973) I9I-20I. For more recent descriptions and interpretations see Cruciani (2000); North (2012) 56-62.

32 It seems that the identification had already been advanced immediately after the discovery, but with scepticism, and without finding its way in a publication before the one by Densmore Curtis, after it was rejected by the archaeologist responsible for the first reports on the Basilica, F. Fornari: cf. Bendinelli (I926) col. 647 (with the criticism of Hubaux (I932) 376).

33 Cf. Carcopino (I926) $3^{82}$ (= (2020) 255): first in Carcopino (I923) 20. In greater detail in Carcopino (I956) I4-23.

34 Among more recent interpretations see especially North (2012). 


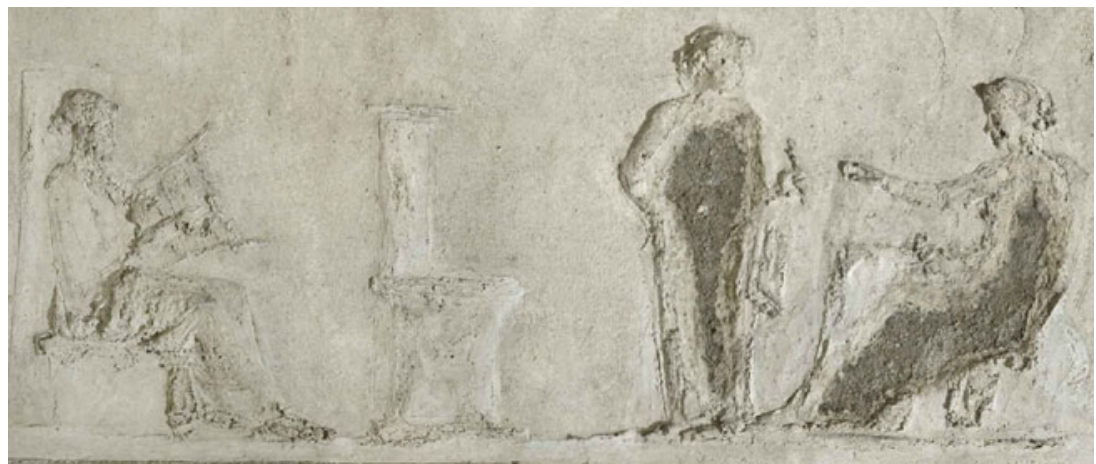

Figure 2a. Detail of a panel from the vault of the right nave of the underground Basilica near Porta Maggiore. ( ) Soprintendenza Speciale Archeologia Belle Arti e Paesaggio di Roma

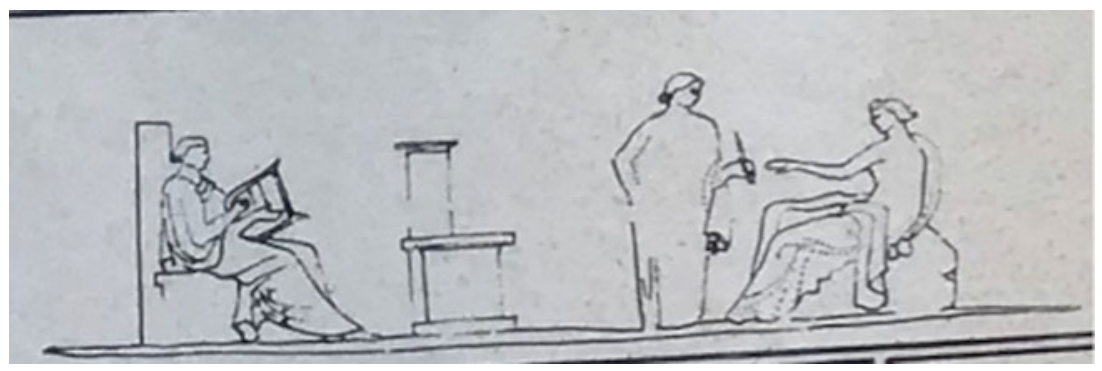

Figure 2b. A drawing of the detail in Fig. 2a. Source: Bendinelli (1926), Table xxvI

Within the very rich iconographic project of the Basilica there is another image that might be relevant to our argument. On the ceiling of the right (south) nave several scenes have been identified as representations of the blessed afterlife, along with mythological ones that can be read with varying degrees of certainty as exemplary for the various destinies of the soul. Among these scenes there is one depicting three wreathed female characters (Figs. $2 a$ and $2 b$ ). The one to the left, entirely wrapped in her garments, is sitting facing the other two characters and is playing a musical instrument, identified by Carcopino as a lyre, and more precisely, by Bendinelli, as a triangular harp: he calls it a $\tau$ íf $\gamma \omega v o v$, but given its shape it could be rather

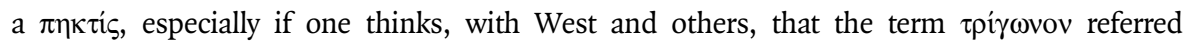
more particularly to the right-angled 'spindle harp'. ${ }^{35}$ The second character, to the right of a

35 Cf. Strong and Jolliffe (I924) 94 (no description); Carcopino (I926) I43 (= (2020) II6, dubiously a lyre); Bendinelli

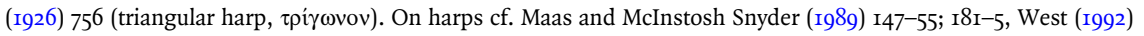

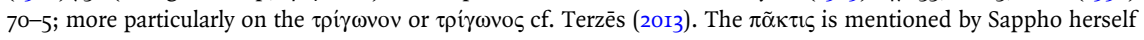
(fr. 156 V. and perhaps fr. 22.II; cf. Alcaeus fr. 36.5 V.), and Menaechmus, On Artists (FGrH I3I F 4a and 4b in BNJ) states that Sappho was either the inventor or the first to use it (cf. Maas and McIntosh Snyder (1989) 40-I; Yatromanolakis (2007) 108, 228-9). In the stucco one would expect the instrument to be placed firmly by the 
small altar placed before a pillar, ${ }^{36}$ stands facing a female figure (with bare shoulders, i.e. younger?) seated to her left, to whom she seems to be giving an object which has been very dubiously interpreted as a plectron (Carcopino (1926) I43). To judge from the most recent available image (Fig. 2a), it looks more as if she is a holding an ampoule with a long neck and a single handle (a small lekythos?), while the woman in front of her is extending a small cup (?) in her right hand (in any case, the kind of harp represented in the same scene was not played with a plectron). Strong and Jolliffe (who label this a 'Group of Muses (?) or of initiates') compare the scene to the 'sacred conversations' of Renaissance painting ((I924) 94 n. 8I), Carcopino gives it the vaguely suggestive label of 'mystic concert', while Bendinelli, with some reservations, interprets it as a music lesson. If we should indeed imagine that the scene takes place in the Underworld (as all scholars seem to do), it would be very attractive to link the wreathed female figure playing the string instrument with Sappho, to whose underworld performances we shall have occasion to return. ${ }^{37}$

\section{Sappho rediuiua?}

It is of course not necessary to suppose that the character who has just returned from the Underworld in the Miners was represented as an 'initiate', since Pherecrates' parody focuses on other aspects. There are, however, several good reasons to think that this character is likely to have been Sappho herself. We have examined above the evidence for her presence on the Athenian stage in the fourth century, and the clues pointing to possible earlier comic Sapphic links already in the fifth century. There are other reasons for proposing this identification. An important recurring theme in Old Comedy is that of bringing back to life on stage ancient characters either through a visit to the Underworld (katabasis) or by having them return to the upper world (anabasis). Examples of this include Cratinus' Archilochoi and Cheirones (and perhaps also Laws, according to Bergk's reconstruction), Telecleides' Hesiodoi, Aristophanes' Gerytades and Frogs, and Pherecrates' Krapatalaoi (besides, of course, his Miners). ${ }^{38}$ In some of these plays, known through a number of fragments and quotations (twenty or more) far greater than is the case of the Miners, we can reconstruct the presence and the identity of the revenant only on the basis of a single piece of evidence. In the Cheirones we can recognise Solon as a persona loquens only because of a quotation of a line in Diogenes Laertius (fr. 246 K.-A.). In Pherecrates'

player's left thigh; from the image its apex seems to be hidden by the player's body; Maas and McInstosh Snyder (I989) I82 mention a case where the instrument 'has no visible support'. The few images in Vendries (I999) are all of right-angled harps, but more curved shapes, at more acute angles, as in our case, are attested (cf. for example a wall painting probably from Boscoreale in the Landesmuseum Württemberg, Arch 83/r k and Lawergren (20II) 28 Fig. 2, with the reproduction of a bas-relief with a Dionysiac scene, without reference).

36 The pillar is identified by Strong and Jolliffe (I924) 94; Bendinelli describes it as a second chair, but its seat would be far too high, and the shape different from the one to the right; Carcopino (I926) I42 (= (2020) II6) sees, correctly judging from the new image, an altar in front of a pillar (not a baetylus, as in the Italian translation).

Cf. below, p. I5.

Cf. Rehrenböck (1987); Urios-Aparisi (1992) 5I, 54, 6I; Franchini (2020) 13, 59 (Aeschylus in Krapataloi); Bagordo (2013) II7 and n. II7, with bibliography; and Bianchi (2016) I7-I8. We do not know anything, apart from its telling title, about Nicophon's The One Returning from Hades (cf. Pellegrino (2013) 55). 
Krapataloi we know about Aeschylus' presence thanks to a single witness, a scholion on Aristophanes' Peace (fr. roo K.-A.). The fact that no witness mentions Sappho's presence in the Miners (a play of which we have just two substantial fragments) cannot therefore be considered as a cogent objection to the identification proposed here.

The identification of 'character A' with Sappho, rather than with some figure influenced by the Sapphic tradition, seems compelling. Not only is Sappho very well known for her fatal dive into Tartarus. Several of her fragments suggest a vision of the poetess's privileged position in the Underworld. Moreover, almost all of the revenants of Old Comedy are, in fact, poets (with a very small minority of politicians, as in Eupolis' Demoi and, perhaps, Taxiarchoi). ${ }^{39}$ And in this category it would be very difficult to find a better alternative to Sappho.

\section{Acherusian vegetation}

The content of the two lines uttered by 'character B' in fr. II3 is not the only clue suggesting a link with Sappho in what remains of the comedy. ${ }^{40}$ The only other fragment of this comedy containing more than a single word, fr. II4 K.-A., from a lyric portion of the play, provides a description of individuals walking within a landscape of blooming vegetation:

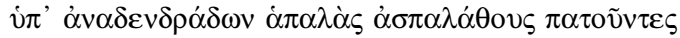

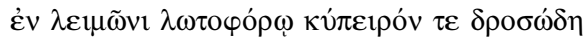

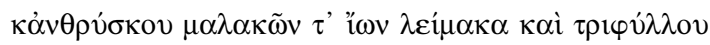

... treading over delicate brambles under climbing vines, ${ }^{4 \mathrm{I}}$

in a meadow rich in lotus, and dewy galingale

and a garden of chervil and soft violets and clover.

These words were probably sung by the chorus, and it has been very reasonably assumed that the landscape described here was the place where the blessed dwell, where flowering meadows are a common topos in literary representations. ${ }^{42}$ Within these topical

39 On Demoi cf. Telò (2007) 24-44 (Telò argues that Pyronides tried to bring back to life also the lyre-player Phrynis) and Olson (2017) 295-310.

40 Within fr. II 3 a further link is arguably provided by the use at line 29 of $\rho$ ó $\delta \alpha$ ('roses') to indicate the female genitalia of the girls serving fragrant wine in the Underworld. The metaphor is clear and there are more or less close parallels

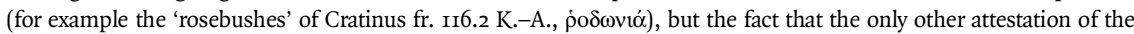
term itself in this sense occurs in Hesychius, $\rho 403$, where the gloss is attributed specifically to the Mitylenaeans, is certainly significant. Other interesting potential links have been suggested to me by Lucia Prauscello (1. $26 \tau \dot{\alpha} \delta \dot{\varepsilon}$

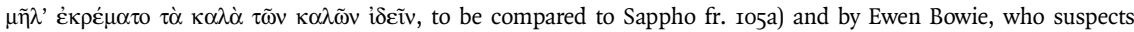
that $\mu$ vppivolor at line 25 might reflect a lost Sapphic background that may lie also behind Longus Sophista 2.4

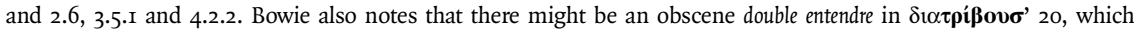
would depend on how the actor spoke the word (since the compound verb seems innocent).

4I For a good explanation of the difficult oxymoron (built upon a sound play that almost suggests para-etymology) cf. Conti Bizzarro (1990-3) I02.

42 Cf. for example Rehrenböck (I985) I73; Urios-Aparisi (I992) 356-62. For the problems related to the attempts at identifying the various botanical species mentioned in Sappho cf. Waern (I972). 
coordinates, however, two elements point decidedly towards Sappho. The first is the

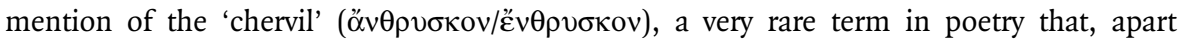

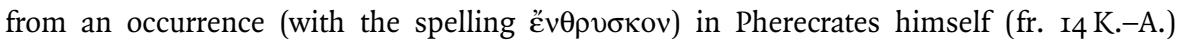
and, probably, in Cratinus fr. 105.6 K.-A. (within a list of flowers used for crowns), has a precedent only in Sappho fr. 96, in the famous description of the moonlit landscape within a simile (ll. I2-I4): ${ }^{33}$

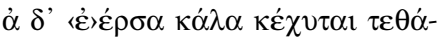 \\ $\lambda \alpha 1 \sigma l \delta \dot{\varepsilon} \beta \rho o ́ \delta \alpha$ кö $\pi \alpha \lambda$ ' öv-

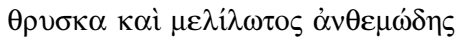 \\ ... the beautiful dew is shed, and roses bloom, and delicate \\ chervils, and flowery melilot.}

Even more interesting is the presence in this context of the terms (not reciprocally linked, but in close proximity) $\lambda \omega \tau$ $\varphi$ ó $\omega$ ('rich in lotus') and $\delta \rho \sigma \sigma \omega \delta \eta \eta$ ('dewy'), which can be read as an echo of the $\lambda \omega \tau$ ivors $\delta \rho o \sigma o ́ \varepsilon v \tau \alpha \varsigma[0] \chi[\theta]$ ors, the 'the dewy banks, covered in lotus', of Acheron, that Sappho, in her desire to die, longs to see in fr. 95 (transmitted by the same parchment as fr. 96$):{ }^{44}$

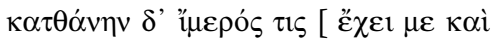

$\lambda \omega \tau$ tivors $\delta \rho о \sigma o ́ \varepsilon v \tau \alpha \varsigma$ [ ö-

$\chi[\theta]$ ors $i \delta \eta v$ 'A $\chi \varepsilon \rho[-$

... and a desire to die [seizes me

and to see the dewy banks, covered in lotus, of Acheron. ${ }^{45}$

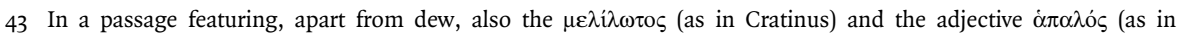
Pherecrates): the two passages from Cratinus and Pherecrates are cited in the apparatus of the loci similes in Voigt (197I) on fr. 96 (not on fr. 95), but Sappho does not feature in the apparatus of Pherecrates in K.-A. Urios-Aparisi (I992) ad loc. cites the Sapphic passages (among others) and has useful remarks on Sappho's influence on Pherecrates' lyrics (356), but has nothing to say on the Acherusian background of the two passages and makes no connection with fr. II3.

44 On the 'lotus' of these lines, and on its Homeric background and its echo in Sappho's Epistle to Phaon, see D'Alessio (2018) 97-8. Apart from the passages related to the interpretation of Il. I4.348 (one of Sappho's models), these seem to be the two only attested passages where terms connected to $\lambda \omega \tau$ to $\varsigma$ and $\delta \rho$ ó $\sigma \varsigma$ are collocated in proximity, a proximity made even more significant by the shared context of a description of a locus amoenus in the Underworld (an element lacking in the Iliad passage). Pherecrates' passage might be influenced also by the

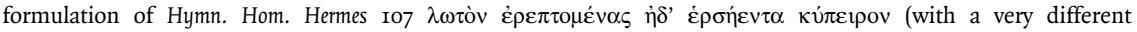
contextual background, of the fodder of the cows stolen from Apollo, cf. also Od. 4.603).

45 The text is lacunose and uncertain, but the sense is clear enough. 
This is yet another tessera contributing to my argument that 'Sappho' in this play was not just an intertextual reference but a central topic and, arguably, a stage character, playing an important role in the construction of the image of the Underworld.

\section{Sappho in the Underworld}

Even allowing that most of the elements of the description of the Land of Cockaigne in the Pherecrates' passage are to be read as variations on a well-established comic topos, we should pay due attention to the fact that there are, in our extremely lacunose corpus, several elements in Sappho's own texts that may contribute to understand the reasons of her choice as a herald of a blessed afterlife.

The fragmentary nature of these texts requires, of course, some caution in their interpretation. However, notwithstanding some recent attempts at playing down their import, ${ }^{46}$ I think that there should be no substantial doubt that they, at the very least, suggest Sappho's peculiar, positive vision of her destiny in the Underworld. This is not to say, however, that the surviving texts should be read as the expression of a group of initiates, or as reflecting mystery cultic practices. ${ }^{47}$

In fr. 95, which we have just examined, a character (probably Sappho herself), persona loquens in the song, in a moment of discomfort expresses her wish 'to see the dewy banks of Acheron, covered in lotus', in terms that clearly present such vision as providing relief and consolation, thus innovating upon epic models. ${ }^{48}$ In two other fragments, 55 and $65,{ }^{49}$ the text describes a condition of fame (of the poetess herself) or of lack of fame (of a woman she criticises) that is going to continue 'even in Hades' or 'even on Acheron's banks'. ${ }^{50}$ The clear implication is that Sappho reckons herself among the individuals who will enjoy the effect of fame even in the Underworld. ${ }^{{ }^{\mathrm{I}}}$ A situation in which Sappho enjoys even in Hades, along with Alcaeus, the admiration of her audience is indeed depicted by Horace in Carm. 2.13.29-30 utrumque sacro digna silentio | mirantur umbrae dicere, 'the shades admire both of them while they recite poems worth of a sacred silence'. In a Sapphic fragment, which in a Ptolemaic papyrus precedes the poem beginning with lines

46 Cf., with different nuances, Palmisciano (1998); Burzacchini (2007); Bettarini (2008); Palmisciano (2017) I44-53, with further bibliography.

47 Cf. Hardie (2005).

48 Good remarks in Boedeker (1979) (her caution regarding the fact that the desire was uttered by the persona loquens seems excessive to me): the objections of Palmisciano (1998) 193-4 do not affect the very significant fact that the representation of Acheron as a place one longs to see has no parallel in previous models.

49 On fr. 65 see also Ferrari (2007) 62-70 (the question whether this fragment can be joined to other ones has no consequences for the issue we are examining here).

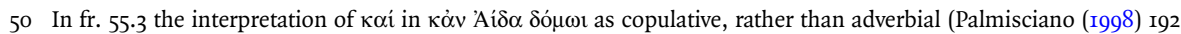
and n. 33), is impossible (as acknowledged now also by Palmisciano (2017) 145 n. 70 and I46).

5I If the fame, and the lack of fame, are located in the Underworld, an explanation focusing on the 'perpetuarsi del canto - e della connessa fama - presso le generazioni a venire', rather than on the 'non dimostrata fede saffica in qualche forma di "esistenza” ultraterrena o di immortalità dell'anima' (Burzacchini (2007) 49-50), cannot be adequate. 
IIff. of fr. $5^{8}$ (P.Köln. inv. $2135 \mathrm{I}+2 \mathrm{I} 376$ ), a badly damaged textual sequence suggests a comparison between the condition of the poetess 'now on earth' (1. 6) and that 'under the earth' (l. 4). ${ }^{52}$ In the same context the text mentions the fact that 'she enjoys a

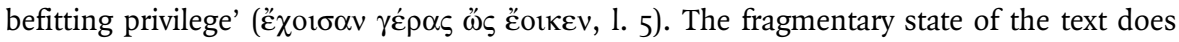
not allow absolute certainty, but everything leads us to think that, as in Horace, the poetess did envisage a continuation of her musical and poetic practice in the Underworld. ${ }^{53} \mathrm{~A}$ musical performance in the Underworld, or at least related to the Underworld, seems to be alluded to also in a late third-century epigram by Dioscorides, where Sappho is imagined as performing a thrēnos for Adonis together with Aphrodite: 'or, while performing a dirge together with Aphrodite, who mourns the young offshoot of

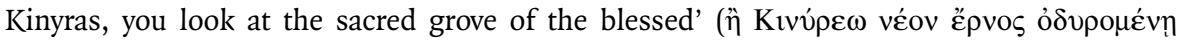

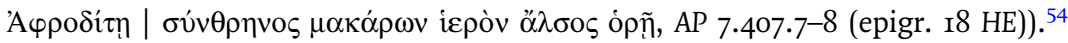

The much-debated fr. I50, addressed by Sappho to her daughter, should be read against the background of the elements examined above:

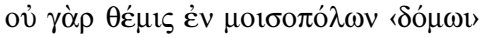

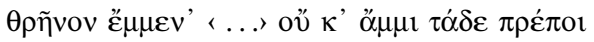

$\ldots$ as it is not right that there should be a funereal song in <the house>

of the servants of the Muses <.. > this would not befit us.

To say that the funereal song should be banished from the house of the poets (in the sense, that is, that one should not sing such a song for them: the fact that on other occasions poets should or could compose funereal songs for others is not at issue here) is clearly a paradoxical statement that scholars have attempted to neutralise in various ways, adding more or less arbitrary qualifications (of mode, of time, of place) for the performance of such a funereal song, ${ }^{55}$ qualifications, however, absent in the text, and whose casual

52 Bettarini (2008) 30 reconstructs the poem's meaning with Sappho stating: 'quando invece vecchia morirò e sarò sotto terra, pur tenendo l'insigne funzione che è propria dei cultori delle Muse, come si conviene, non potranno più ammirarmi (scil. le mie compagne) come ora che sono sulla terra'. Such a reconstruction betrays an intrinsic rhetorical weakness (an incongruous invitation to 'celebrate me now, since it will not be possible anymore once I am dead', with a very unlikely emphasis on the fact that, once dead, Sappho will not enjoy 'the privilege that befits her now on earth') and is explicitly built on the postulate that Sappho could not possibly envisage for herself a privileged status after her death.

53 Palmisciano (2017) I48 rules out that Sappho might have envisaged a privileged existence 'in Hades' (as opposed to the destiny of the ancient heroes, located in the Islands of the Blessed). This opinion, however, is based on the idea that the positions emerging from Sappho's texts should not diverge from the 'traditional' ones, thus obliterating the elements of strong, even paradoxical, innovative charge that Sappho's poetry often displays (Palmisciano (2017) I48-9, on the other hand, acknowledges that Horace 'sembra confermare quanto la stessa Saffo affermava nel carme del Papiro di Colonia, cioè che nell'aldilà avrebbe continuato a eseguire i suoi versi come faceva in vita').

54 The relevance of this passage was pointed out to me by Serena Cannavale. Gow and Page (I965) 250 note that 'it is

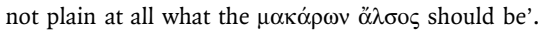

55 See Palmisciano (1998) and (2017) 152-3; Bettarini (2008) 24-5; cf. also the slightly different position of Burzacchini (2007) 52-4, who limits the prohibition only to 'unseemly' ('scomposte') performances: these 
omission is made unlikely by the context itself of the quotation. ${ }^{56}$ Barring contrary evidence, our source attributes to Sappho an absolute refusal of a funereal song for the servants of the Muses. And this is clearly because, in contrast to what one can imagine for common mortals, for whom death is naturally evil, ${ }^{57}$ the poetess envisages for herself (exactly qua poetess) a privileged existence in the Underworld, where she would have continued to compose and perform songs, enjoying the admiration of her audience, as suggested also by the fragments examined above, and by Horace's vision.

\section{Returns of Sappho}

With the exception of Pherecrates' Miners (if my argument holds), and of the potential clues in the iconography of the Porta Maggiore hypogaeum, no ancient document offers glimpses on the ultimate fate of Sappho after her dive from the Rock of Leucas. Death or liberation from her sufferings? Sappho's Epistle, for obvious reasons, stops immediately before the last fatal decision. Ovid's friend, the poet Sabinus, author of the lost poetic replies to the Heroides, must have envisaged a happy ending, as testified by Ovid himself in a famous and tormented passage of his Amores (2.18.34 dat uotam Phoebo Lesbis amata lyram, 'the Lesbian one, having become the object of love, gives to Phoebus the lyre she had promised as a vow'). The outcome here did not involve death, or deliverance from love, but Sappho's dedication of her lyre, ex uoto, to Apollo, out of gratitude for her now requited love with Phaon (cf. Rosati (1996)). Her fatal leap, however, was to become the motif that more frequently marked Sappho's reception from the Renaissance onward. Even if only for the sake of providing a satisfying narratological denouement, the riddle of its outcome had to be faced and solved.

To my knowledge, one of the earliest modern representations of Sappho's suicide is that found among the illuminations (attributed to the circle of Jean Pichore) that adorn a copy of the late fifteenth-century French translation of the Heroides by Octovien de Saint-Gelais in fol. I97v of the manuscript Parisinus Fr. 874, produced towards the end of the first decade of the sixteenth century at Rouen, in the milieu of Cardinal Georges d'Amboise (Fig. 3). The image of the woman, chastely dressed from the top of her head to the tips of her feet, falling on the ground (not into the waves), with a rivulet of blood, leaves no doubt about the outcome of her decision. It would be hard to reconcile this iconography with the character of the sexually outspoken poetess in the Ovidian Epistle. This manuscript features some peculiar prose introductions to the Epistles, some of which

publications offer ample bibliography on the issue (including Cannatà Fera (1990) 12, on the semantic overlap between $\theta \rho \tilde{\eta}$ vo

56 It is likely (as suggested also by the metre) that Maximus of Tyre did omit a few words when citing these lines. It is very unlikely, however, that such omission involved implications about important qualifications on the issue that was crucial to Maximus' purpose (in his text the citation buttresses a comparison with the behaviour of Socrates in Plato's Phaedo, banishing lamentations for his impending death, and ordering that Xanthippe leave the room).

57 According to Arist. Rh. 2.1398b (test. 20r V.), Sappho thought 'that death was evil: the gods decided thus, otherwise they would die'. 


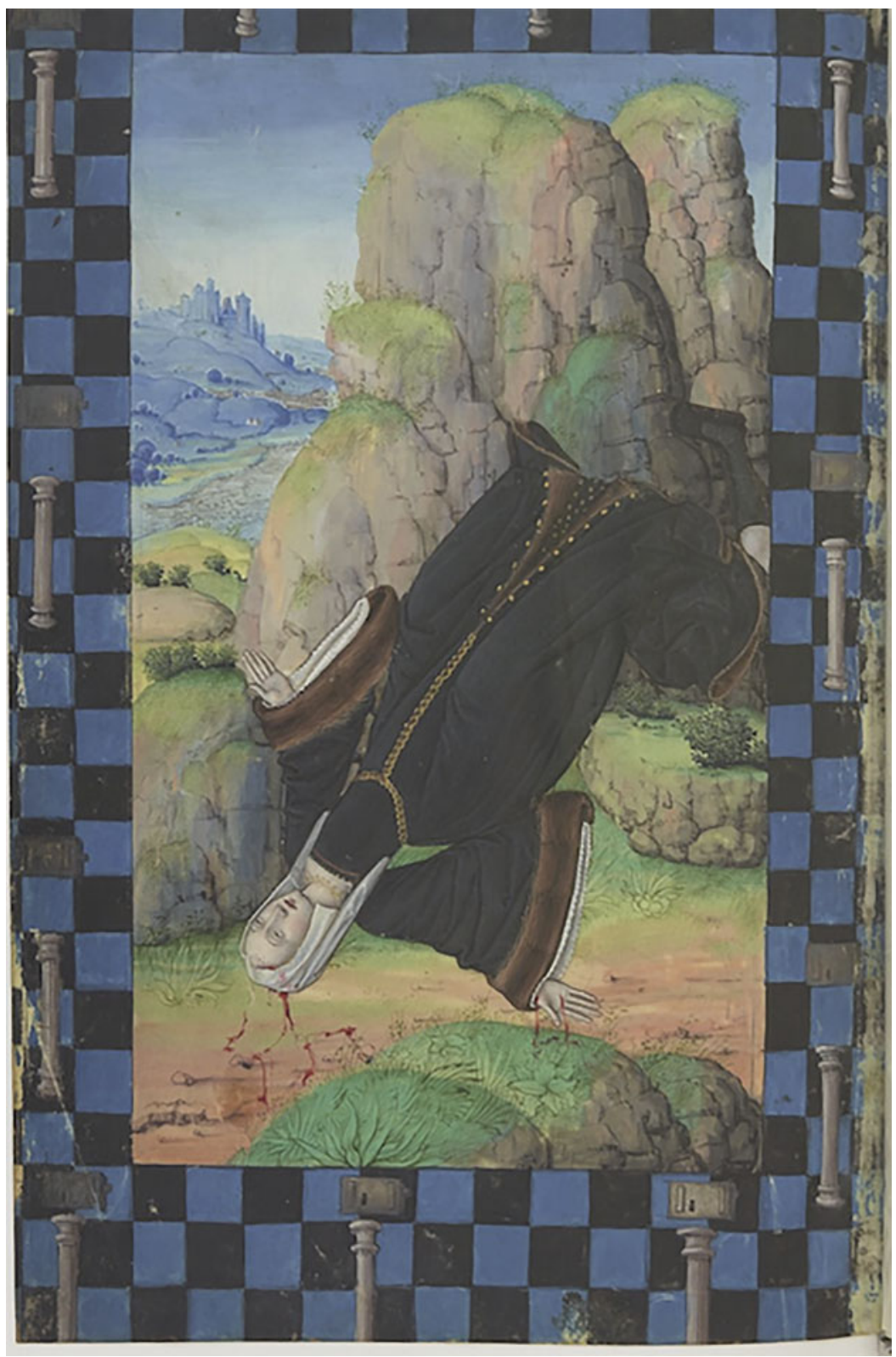

Figure 3. Parisinus Fr. 874, fol. I97v. Source: Bibliothèque national de France, Département des manuscrits 
situate the events in Normandy (cf. Durrieu and Marquet de Vasselot (I894) I4-I5; Brückner (I989)). In the prose introduction to her Epistle, Sappho is presented as a 24-year-old widow, 'royne de Pirnance', discoverer of music and instruments, who falls in love with Phaon, the already-married 28-year-old son of a rich Sicilian merchant, who has arrived with his ship in her port, in a city called 'Tollo'. ${ }^{8}$ It does not seem to have been noticed that in this manuscript the French text of Sappho's Epistle all too significantly modifies the gist of the original translation of de Saint-Gelais, in a way that makes its character much more compatible with her visual representation. Its text, for example, has eliminated all references to Sappho's earlier homosexual loves. Lines $15^{-20}$ of the Latin Epistle refer to Sappho's rejection of her previous female loved ones after she fell in love with Phaon. In all the other manuscripts I have consulted, ${ }^{59}$ and in the early printed editions which I was able to access, these lines are rendered, with a certain degree of looseness, and with several problems regarding the interpretation of the Greek proper names, but without altering their substance, in eleven French lines, including a mention of 'les trois pucelles que j'ay si fort aimée' and of 'Atthis si belle et que tant fort valoit', who 'plus ne me plaist ainsi qu'elle souloit'. In Fr. 874, on the other hand, the whole section is rewritten and slightly abridged (it corresponds to only seven lines in the French text) in such a way as to delete any possible allusions to homosexual inclinations. ${ }^{60}$

Two other manuscripts of the translation, London, British Libr., Harley 4867 and Oxford, Balliol College Libr., 383 offer a (slightly earlier, probably late fifteenth-century) representation of Sappho immediately before her leap (the Balliol manuscript, Fig. 4) or in the act itself of leaping (the Harley manuscript, Fig. 5). ${ }^{6 \mathrm{r}}$ In both cases the image is remarkably different from that of Paris, BnF, Fr. 874: Sappho is not veiled and has with her signs of her poetic/music activity (a lute and a book in the Harley manuscript; a lute and a harp in the Balliol manuscript, which also features a stream of water - a river, apparently, not the sea - under the rock). In neither case is there any hint at the final outcome of her leap. The representations in these manuscripts ${ }^{62}$ precede by very few years the entirely different Sappho of Raphael's Parnassus in the Stanza della Segnatura

58 Cf. Hériché-Pradeau (2020). Perhaps the two toponyms stand for Provence and Toulon?

59 Vienna, Österreichische Nationalbibl., 2624; London, British Libr., Harley 4867; Oxford, Balliol College Libr., 383 ; Paris, Bibliothèque de l'Arsenal, Ms. 5108 réserve (which bears a dedication to Charles VIII); Paris, BnF, Fr. 875 (produced for Louise of Savoy, illuminated by Robinet Testard, and dated around 1497), Fr. 873 (also produced for Louise of Savoy - or for King Louis XII and later passed to Louise of Savoy ? - illuminated by Jean Pichore). On the relationship between Frr. 873 and 874 cf. Pollock-Renck (2019). For a complete list of the manuscripts and of the printed editions see F. Duval, in Miroir des classiques (École nationale des chartes), available at: http://elec.enc. sorbonne.fr/miroir_des_classiques/xml/classiques_latins/heroides_ovidius.xml, accessed I8/I2/2020.

60 It is a general tendency of this manuscript to offer an abridged text; cf. Brückner (I989) 94-5. Sappho's Epistle here has 372 lines against the 532 lines of the normal text. Brückner (1989) does not elaborate, though, on the impact of such abridgments on the content, an issue which would be worthy of more detailed analysis. For other cases of manipulations in early modern and later Italian translations of Sappho's Epistle to Phaon see Cesaro (2015) and Galbiati (20I5).

6I Cf. Saxl and Meier (I953) I9I-3 and 409-I2. On the Balliol manuscript cf. Mynors (I963) 360-I.

62 In all the other manuscripts I have been able to consult the representations of Sappho are not related to her leap. In San Marino, Huntington Libr., H M 6o (whose text of the Epistle I have not been able to access) she appears (as 


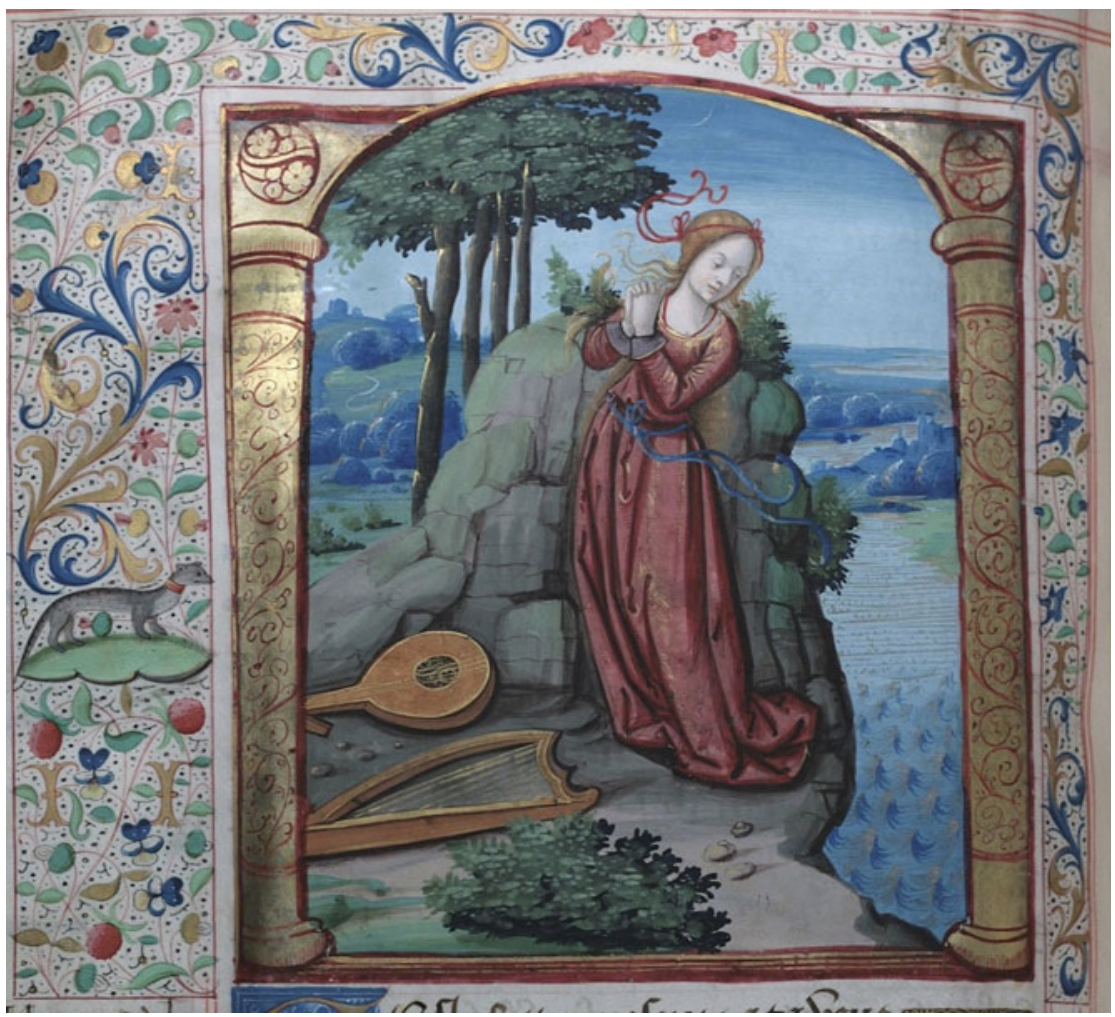

Figure 4. Oxford, Balliol College Libr., 383, fol. I67v. Reproduced by permission of the Master and Fellows of Balliol College, Oxford

(I5IO-II), which also (albeit in a very different way) reflects the legacy of the Ovidian Epistle if, as it has been convincingly assumed, the roll with her name the poetess holds in her left hand is to be interpreted as the famous signature/name of the Epistle itself. ${ }^{63}$

The difference from the illumination of the French Heroides is not only a matter of classical sensuousness: in representing Sappho on his Parnassus, Raphael effectively anticipates the sublimation of her worldly suffering resulting in the triumph of poetry. When, in fact, Sappho entered the narratological engine of more complex constructions, the suspended outcome of the Heroides tradition was bound to become a problematic dénouement, and the heroine's reaching a state of liberation or even apotheosis is revealed as an almost unavoidable solution allowing the granting of a happy ending to the story.

in most other cases) in the act of writing her letter, and with an attire as chaste as that of BnF Fr. 874 and even more sumptuous.

63 On Sappho in Raphael's Parnassus cf. Cannata Salamone (2002) 49-54, with bibliography. 


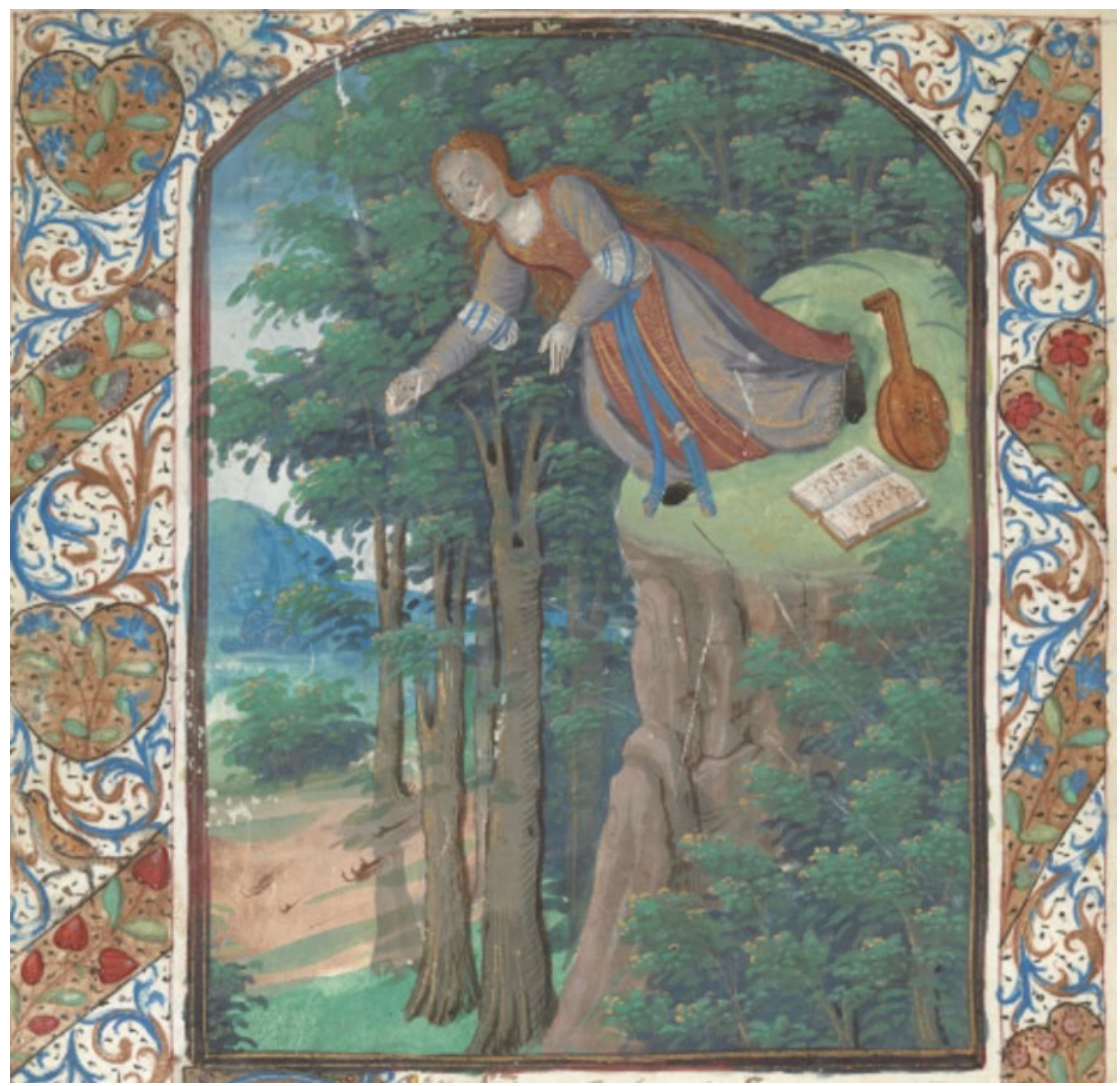

Figure 5. British Library, Harley 4867, fol. I77v. Reproduced by permission of the British Library

The first 'literary' work, to my knowledge, that moves clearly in this direction is the opéraballet Le triomphe des arts, with a libretto by Antoine Houdar de la Motte and music by Michel de la Barre, performed at the Académie Royale de Musique on I6 May I700. ${ }^{64}$ Its second entrée has as its theme the Triumph of Poetry exemplified by Sappho who, made desperate by Phaon's rejection, reacts, once again, with her suicidal move, jumping down from the Rock. In Scene vi a repenting Phaon mourns her fate and asks the music to cease, but Neptune informs him that the poetess has become a goddess, one of the Muses: 'Cesse de plaindre une déesse: | Sapho prend sa place en ce jour | entre les filles de

64 DeJean (I989) 257 mentions as the first instance of Sappho's apotheosis the considerably later opera Sapho by Vénard de la Jonchère (I772). 
mémoire. | Le Ciel qui prend soin de sa gloire | veut l'égaler a son amour.' Houdar de la Motte had no ancient precedent for this narratological solution (the only parallel being the Greek epigrams where Sappho is presented as the tenth Muse), and in his introductory notes defends the innovative character of his choice, even regretting that he did not give more space to a proper representation of the welcome of Sappho on Parnassus. ${ }^{65}$ This absence of precedent is made good for in Vénard de la Jonchère's Sapho (I772), where the poetess is the victim not only of Phaon's fickle behaviour but also of Venus' scheming against her. In Act II, Scene VII, in her despair Sapho throws herself from the Rock of Leucas, with an address to Apollo. The god rescues the poetess, bringing her to Parnassus, where she is welcomed by the Muses and rescued, once again by Apollo, also from the menace of Time.

It is against the background of this well-established eighteenth-century tradition of Sappho's apotheosis, which did not entail a properly tragic twist, that in the nineteenth a tradition emerges which attributes to Sappho a self-consciously heroic dramatic character, with F. Grillparzer's Sappho (performed on stage in I8I8). In this play, the superhuman poetess, yet again disappointed by Phaon, moves from a Medea-like revengeful fury to the realisation that she does not in fact belong to the human world, where she will never be able to find happiness, but to that of the gods. This is a recurrent motif in the whole drama, whose final consequence is Sappho's leap from the Rock of Leucas, as a return to her divine status: Act III, Scene II, Il. 947-54 'Hier ist kein Ort für mich als nur das Grab. | Wen Götter sich zum Eigentum erlesen | Geselle sich zu Erdenbürgern nicht ... Von beiden Welten eine muss du wählen. | Hast du gewählt, dann ist kein Rücktritt mehr'; Act v, Scene III, l. I722 (Phaon) 'Zeig dich als Göttin! Segne, Sappho! segne!'; ll. I727-9 'Mit Höhern, Sappho, halte du Gemeinschaft | Man steigt nicht unbestraft von Göttermahle | Herunter in den Kreis der Sterblichen'; 1. I783 'Den Menschen Lieb, und den Göttern Ehrfuhrcht' (a line repeated by Sappho in her very last words, Act v, Scene vI, ll. 2025-8); Act v, Scene vI, ll. 204I-2 (Rhamnes) 'Es war auf Erde ihre Heimat nicht | Sie ist zurückgekehret $\mathrm{zu}$ den Ihren' (the drama's last words). ${ }^{66}$ Along similar lines we should read also the interpretation of Sappho proposed in J. J. Bachofen's Mutterrecht (I86I), where Sappho is seen as the priestess of the great mother-goddess, identified with Aphrodite: 'So ... umschliesst Sappho in der Welt ihrer Gefühle alle Seiten der Göttin, der sie dient, mit welcher sie daher auch in der Volkstradition von dem jetzt menschlich gedachtet Phaon und dem Leukadischen Sprung zu Einer Gestalt verschmolzen erscheint. ${ }^{67}$

65 In his Rèponse à la critique following the libretto, printed also on pp. 209-2II of volume vi of his Oeuures. Sappho's assumption to Parnassus arguably reflects that of Madame Deshoulières in Le triomphe de Madame Deshoulières of Marie-Jean L'Héritier (1694): cf. Cowart (2008) I75 n. I5 (quoting Denis (2001) 75-7 (non uidi); cf. also DeJean (I989) II4). On the Le triomphe des arts as a vehicle of libertine ideology in opposition to that of Louis XIV's military absolutist monarchical ideology, and on the importance of the choice of Sappho as the representative of the triumph of Poetry, see Cowart (2008) 173-9.

66 Cf. DeJean (1989) I93-6; also Most (1995) 23-4, but without the crucial connection to eighteenth-century apotheoses.

67 Bachofen (1861) 345. Bachofen compares Sappho to Diotima and Theano, attributing to them an OrphicPythagorean religious philosophy: cf. DeJean (I989) 220-I, who (see also 347 n. 22) underlines the affinity to the modern interpretation of the character in the Porta Maggiore Basilica. In the year after the publication of 
This is not, however, the only way in which Sappho's fate was presented in the nineteenth century. It is easy to compare and contrast Grillparzer's apotheosis with the stark refusal of any possible consolation in Leopardi's Ultimo canto di Saffo (I822), where the poetess imagines herself in a bleak Underworld ('rifuggirà l'ignudo animo a Dite', 1. 56; 'e il prode ingegno | Han la tenaria Diva | E l'atra notte, e la silente riva', ll. 7I-2, the poem's final lines). All of this reflects Leopardi's own outlook and can be contrasted with Sappho's actual terms of representation of the Underworld, described above (pp. 15-17). In particular it radically reverses the description of the dreary destiny of the soul of the woman who does not partake in the roses of Pieria (fr. 55).$^{68}$ In this Leopardi had an interesting antecedent in Vincenzo Maria Imperiali's Faoniade, a collection of hymns and odes of 'Saffo' (presented as 'translated' from Sappho) arranged as part of a biographical trajectory and published for the first time in Venice in 1780 , and then several times well into the nineteenth century. In the last ode of the second part, titled A Vow to Apollo, Imperiali's Sappho envisages two possible outcomes of her leap. The first one is explicitly based on what is now our fr. 55, but transforms Sappho's address to another woman into a self-address:

Se andrai dell'Orco orribile

Nei regni oscuri e mesti,

Del nome tuo memoria

Più non sperar che resti.

Più non sarai partecipe

Delle purpuree rose

Che del Parnaso colgonsi

In su le vette erbose:

Ma ignota andrai dell'Erebo

Per la region fumante,

Tra l'ombre tristi e pallide

Eternamente errante. ${ }^{69}$

Bachofen's influential book, the story of Sappho and Phaon and the leap from the Rock of Leukas was interpreted in mythological terms by Kock (1862), who developed an idea already formulated by Müller (I840) 174, who saw Phaon as a mythological equivalent of Phaethon: Phaon is a hypostasis of the Sun god, while Sappho is etymologically explained from the adjective $\sigma \alpha \varphi n$ 's as 'die helle, schimmernde', 'the bright, shimmering one' (86). This is an interpretation that (seldom if ever credited to Kock) reappears, with various modifications, in later scholarly and poetic readings; compare, in the scholarly field, Wilamowitz-Moellendorff (1913) $3 \mathrm{I}-4 \mathrm{O}$ and Nagy (1973), and, in the poetic one, the beautiful creation of Giovanni Pascoli's Solon (1895) (on which see Piantanida (202I) 353-5, with bibliography: Pascoli presents the idea as 'entirely his own' in a letter to his editor, Adolfo De Bosis).

68 On Leopardi's Sappho cf. Piantanida (202I) 349-5I, with bibliography.

69 I am quoting from the re-edition in Favaro (2012) I89 (and I92, for Imperiali's own note connecting this to our fr. 55, which he quotes from the Latin translation of Stephanus' edition; Imperiali was still mocked for his use of the Latin sources by Wilamowitz-Moellendorff (I9I3) I8 n. 2). 
This is followed by an alternative of salvation, even if Imperiali notes that one should believe that in Sappho the fear of death prevailed over the hope of salvation. The latter option is not even envisaged by Leopardi, ${ }^{\circ}$ who, by contrast, anticipates a theme that was to emerge from a later papyrus discovery, i.e. that of Sappho's longing for her own death as an escape from her suffering (which we examined above with regard to fr. 95).

In any case, Sappho's apotheosis and the recognition of her divine nature as envisaged by Grillparzer show obvious limits if we are to move from the development of an (almost mythological) character to that of the reception of a poetic tradition. In later tradition Sappho comes back from her suicidal leap as the ambiguous image of a corpse, or as the symbol of a failure. In Lesbos, a poem first published in $1850^{7 \mathrm{I}}$ before briefly finding place within Les Fleurs du mal in 1857 , soon to be expelled from the collection in the same year as one of the 'damned poems', Baudelaire offers an idealised vision of the island, as a land of full love not subject to the judgement of human or divine morality, and imagines the poet as charged with the mission to wait for the return of Sappho's corpse (11. 46-55, $7 \mathrm{I}-5)$ :

Et depuis lors je veille au sommet de Leucate, Comme une sentinelle à l'oeil perçant et sûr,

Qui guette nuit et jour brick, tartane ou frégate,

Dont les formes au loin frissonnent dans l'azur;

Et depuis lors je veille au sommet de Leucate,

Pour savoir si la mer est indulgente et bonne,

Et parmi les sanglots dont le roc retentit

Un soir ramènera vers Lesbos, qui pardonne,

Le cadavre adoré de Sapho, qui partit

Pour savoir si la mer est indulgente et bonne!

Et c'est depuis ce temps que Lesbos se lamente, Et, malgré les honneurs que lui rend l'univers, S'enivre chaque nuit du cri de la tourmente

Que poussent vers les cieux ses rivages déserts.

Et c'est depuis ce temps que Lesbos se lamente!

70 Cf. Maurer (2000) 230-4. We must note that Imperiali's work is not listed in the catalogue of the imposing library of Leopardi's father, Count Monaldo, at Recanati (Catalogo della Biblioteca Leopardi in Recanati, published as volume Iv of Atti e memorie della deputazione di storia patria per le province delle Marche (Ancona I899)), which was the main source of the poet's extensive readings up to $\mathrm{I} 822$, when he first left his native town. The work would have been easily accessible in the region at the time, however. If this is not the case of direct influence, it is nevertheless indicative of an interesting similarity of approach to Sappho's fragments.

7I In the anthology of Lemer (I850) 469-72. The poem is likely to go back to the second half of the I840s: cf. Pichois (I975) II23-6. 


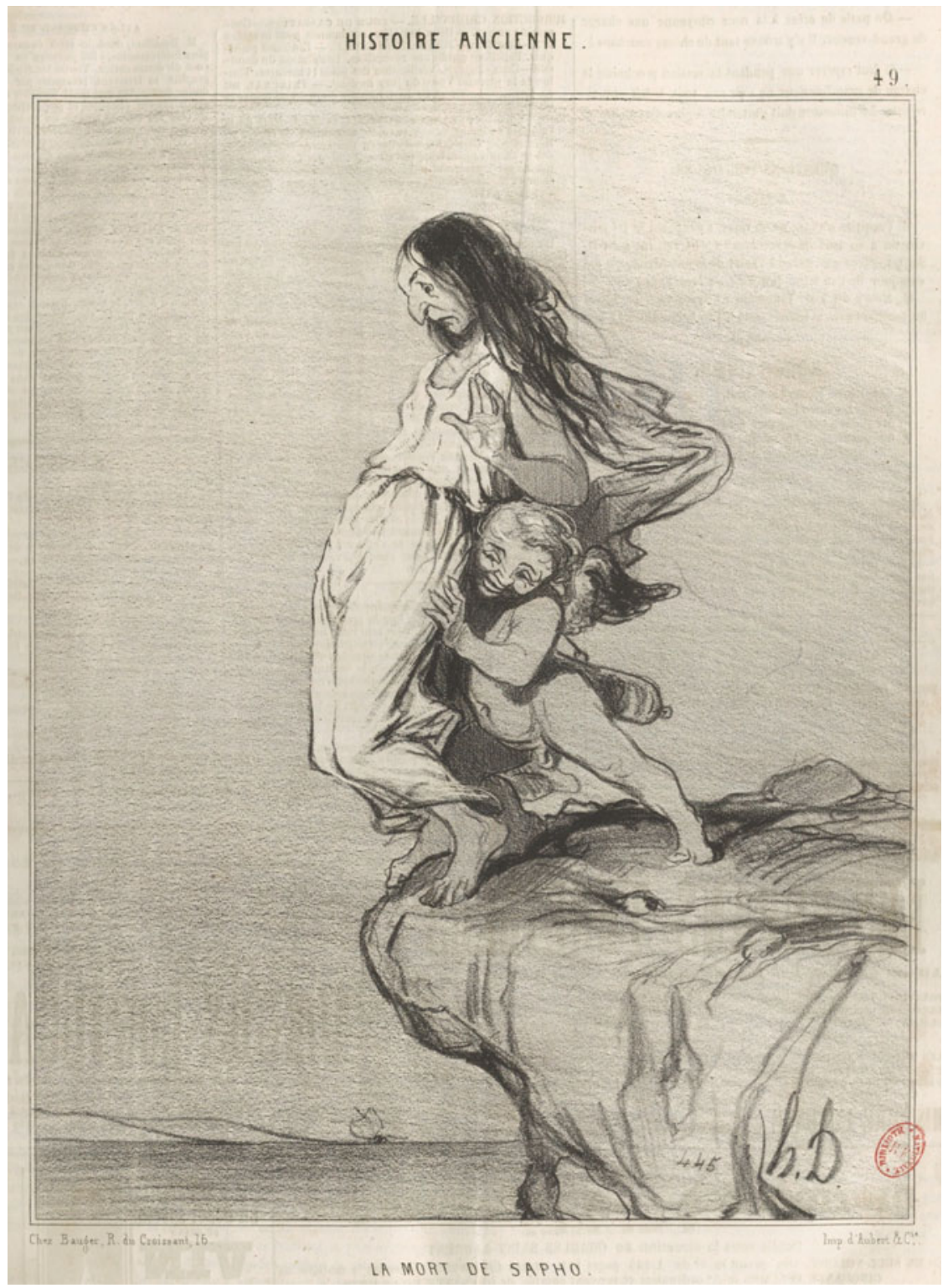

Figure 6. H. Daumier, La mort de Sappho, published in Le Charivari, 4 January I843. Source: Bibliothèque national de France 
Lesbos and the poet wait for Sappho's return, in the expectation that it may bring again to the island the miracle of the arrival of Orpheus' severed head. ${ }^{72}$ This image contributes to the reincarnation of an ambiguous poetic tradition where the object of adoration is, in fact, not a goddess but a corpse. It is a very powerful image whose profound ambiguity affects not only Baudelaire's attitude towards female homosexuality (as shown, among others, also by two other poems of the series Femmes damnées - both originally in the section Fleurs du mal together with Lesbos, and with one of them, Delphine et Hippolyte, also 'damned' and ejected from the first edition of the collection - that represent it under a strongly negative perspective), but also his vision of the relationship with the ancient, classical tradition. Between Lesbos' first publication and that of Les Fleurs du mal Baudelaire had published the essay L'école païenne (in La semaine théâtrale, January 1853) with its resounding rhetorical question: 'Qui nous délivrera des Grecs et des Romains?' There, exalting a collection of cartoons by $\mathrm{H}$. Daumier titled Histoire ancienne, Baudelaire comments:

Daumier s'est abattu brutalement sur l'antiquité et la mythologie, et a craché dessus. Et le bouillant Achille, et le prudent Ulysse, et la sage Pénélope, et Télémaque, ce grand dadais, et la belle Hélène, qui perdit Troie, et la brûlante Sapho, cette patronne des hystériques, et tous enfin nous apparurent dans une laideur bouffonne qui rappelait ces vieilles carcasses d'acteurs classiques qui prennent une prise de tabac dans les coulisses. Eh bien! j'ai vu un écrivain de talent pleurer devant ces estampes, devant ce blasphème amusant et utile. Il était indigné, il appelait cela une impiété. Le malheureux avait encore besoin d'une religion. [Emphasis added]

The reference to Sappho in L'école païenne was inspired by a cartoon where the poetess, aged, unattractive and with almost masculine traits, is pushed, obviously against her will, down from a rock by a little Cupid (Fig. 6). The inverted similarity with the scene in the apse of the Porta Maggiore Basilica (obviously unknown to Daumier: Fig. I) is remarkable. ${ }^{73}$ The use of the terms 'old carcasses' and 'blasphemy' establishes a clear potential link (with a radical inversion of meaning) to the 'adored corpse' of Sappho, and the 'blasphemy' that caused her death in Lesbos ('celle qui mourut le jour de son blasphème', 1. 70; cf. also 1. 66).

This is a very good example of the 'contradiction' typical of the ideology of the Second Empire, which Walter Benjamin saw as one of Baudelaire's key traits: 'The same traits are found in Baudelaire's theoretical writings. He usually presents his views apodictically.

72 The motif of Orpheus' severed head brought by the sea to the shores of Lesbos goes back to the Hellenistic poet Phanocles (fr. I Powell), but Baudelaire would have known it more probably from Ovid, Met. II.50-5 (cf. also Lucian, Ind. II). The idea of Sappho's floating corpse was not unheard of in the nineteenth century: cf. the

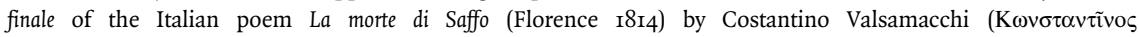
$\mathrm{B} \alpha \lambda \sigma \alpha \mu \alpha \dot{\alpha} \eta \varsigma$, a Greek intellectual from the Ionian island of Cephalonia, just south of Leucas), where after her death, following a prayer by Sappho herself, Apollo inspires a dolphin (the model here is the story of another poet from Lesbos, Arion) to carry her corpse from Leucas to Sicily, where it provokes Phaon's regret.

The affinity is noted by Stein (I98I) I89-9o. 
Discussion is not his style; he avoids it even when the glaring contradictions in the theses he continually appropriates require discussion. ${ }^{74}$ DeJean ((1989) 270-I) reads this contradiction (without exploring the parallels I have highlighted in the text above) as a sort of marketing strategy to mark a difference from other contemporary literary and dramatic Sapphic creations. This, however, runs the risk of concealing the importance of the profound contradiction we find inside Baudelaire's own work (note that he published Lesbos both before and after his 1853 essay). The essay's formulation subverts in a very conspicuous way that of Baudelaire himself in his earlier poem.

The ambiguity of the figure of the corpse/carcass intersects in many ways with the figure of Sappho in Baudelaire. It will be useful to follow it by taking into account Lesbos (now usually read as the second poem of Les épaves) in its original and intended relationship with other poems that appeared in the same section of the first edition of Les Fleurs $d u$ mal in I857. The poem, number Lxxx in the whole collection, was the third in its second section, also called Fleurs du mal. In the original sequence of this section, it was preceded by the poem Une martyre - whose title would have reflected on Lesbos' 'eternal martyre' (ll. 26,30 ) - prominently featuring the voyeuristic description of a female corpse, that of a woman beheaded in her apartment by an unknown lover/murderer. Her 'cadavre impur' (l. 49) thus originally immediately preceded Sappho's 'cadavre adoré' (Lesbos v. 54). Even more crucially linked to Lesbos is another poem, Un voyage à Cythére, number LxxxviII in the I857 edition, and the penultimate in the same section. This poem, which survives also in two manuscript versions, one of which dated January I852, was first published in 1855 but probably goes back, like Lesbos, to the I840s. It was inspired by an 1844 prose piece of Gérard de Nerval, taking the cue from his journey in the region, with an imaginative description of the abysmal gap separating the fantasy of the classicising journey to Cythera from the grim reality of Cerigo (the island's modern, Venetian, name), a barren land whose sight is for the narrator dominated by an imposing tripartite gallows from which a human corpse hangs. ${ }^{75}$ The contrast between idealising classical memory and the rotting carcass is graphically intensified in Baudelaire's poem, in a way that makes its parallelism to Lesbos' Sappho unmistakeable. Lines 9-16, a hymn-like address to the island of Venus, and lines 21-4, evoking (in contrast) the image of a temple scene, recall in their topicality analogous sections of the address to the island in Lesbos:

Ce n'était pas un temple aux ombres bocagères,

Où la jeune prêtresse, amoureuse des fleurs,

Allait, le corps brûlé de secrètes chaleurs,

Entrebâillant sa robe aux brises passagères. (Lesbos Il. 2I-4)

74 Benjamin (2006) 47 (written in 1938).

75 Cf. Pichois (1975) 1069-71. 
The longing for the ancient, feminine ritual scene, however, is substituted in this poem by the spectacle of the hanged corpse of an inhabitant of the island (ll. $4 \mathrm{I}-4)$ :

\section{Habitant de Cythère, enfant d'un ciel si beau, Silencieusement tu souffrais ces insultes \\ En expiation de tes infâmes cultes \\ Et des péchés qui t'ont interdit le tombeau.}

The insult of the capital execution and the public display of the rotting carcass hanging from the gallows is here explained as an expiation for the island's 'infamous cults' ${ }^{76}$ in a way that clearly is meant to mirror the representation of Sappho's impiety ('impiété', Lesbos 1. 69) as the cause of her death: 'qui mourut le jour de son blasphème ... insultant le rite et le culte inventé' (Lesbos $11.66-7$ ). ${ }^{77}$ The narrating voice of the 'poet' closes the poem by fully identifying himself with this rotting carcass: the vision of the ancient ritual is cancelled by 'un gibet symbolique ou pendait mon image ...' (1. 58). ${ }^{78}$ Here we find, again, the contrast between the mirage of the fullness of lost, sensuous, feminine rituals and its transformation, as the result of an act of impiety, into the vision of a corpse. The corpse survives, therefore, both as longed-for 'cadavre adoré' and as a rotting carcass (with which nevertheless the narrating voice of the modern poet of Un voyage à Cythére identifies). ${ }^{79}$ The ambiguity of the two sides of Sappho's reception shows how her fatal leap can shift, once again, from being the symbol of a promise to that of a failure.

The two themes, that of the corpse of the drowned poetess, and that of her rejection in favour of a poetry not bound anymore by the constraints of the past, emerge with clarity in one of the first poems of the American poet Muriel Rukeyser, Poem out of Childhood, published in her first book, Theory of Flight (I935). It will be useful to quote the end of its first stanza:

They who manipulated and misused our youth, smearing those centuries upon our hands, trapping us in a welter of dead names, snuffing and shaking heads at patent truth ...

76 The two earlier manuscripts read 'anciens' instead of 'infâmes': cf. Pichois (1975) I073.

77 In a manuscript note Baudelaire wrote: 'l'incorrigible Gérard [Nerval] prétend au contraire que c'est pour avoir abandonné le bon culte que Cythère est réduite en cet état' (cf. Pichois (1975) I073). This element does not appear explicitly in the prose piece of Nerval, and Pichois conjectures that Nerval may have formulated it in a response to a manuscript copy of the poem that Baudelaire would have sent him, and that it was Nerval's disapproval that caused the omission of a dedication to the friend at the time of the poem's publication. Surely, however, the fact that Nerval had killed himself by hanging a few months before the poem was published goes a long way towards explaining the lack of the dedication in the published poem.

78 As Benjamin (2006) I63 notes: 'Baroque allegory sees the corpse only from the outside. Baudelaire sees it also from within.'

79 We can thus see the narrator of Un voyage à Cythére as an example of the 'talented writer' evoked with sarcasm and commiseration in L'école païenne. 
We were ready to go the long descent with Virgil the bough's gold shade advancing forever with us, entering the populated cold of drawing-rooms; Sappho, with her drowned hair trailing along Greek waters, weed binding it, a fillet of kelp enclosing the temples' ardent fruit: Not Sappho, Sacco. ${ }^{80}$ Rebellion pioneered among our lives, viewing from far-off many-branching deltas, innumerable seas.

Sappho becomes here the image of death by drowning, of a floating corpse that will not land anywhere, ${ }^{8 \mathrm{r}}$ 'trailing along Greek waters', while innumerable seas open themselves to the eye of new generations. In the following year, 1936, Rukeyser would leave the United States for the Spain of civil war.

That same year, 1936 (the book had been completed already in 1935), saw the publication of one of the greatest and subtle re-creations of Sappho in modern and contemporary literature, within the collection Feux of Marguerite Yourcenar (who in 1939 will travel in the opposite direction, towards the United States, leaving Europe on the brink of a war). ${ }^{82}$ The short prose poem that closes the collection (Yourcenar (I936)) bears the title Sappho ou le suicide. It is a text too rich to be more than very lightly touched upon here. Yourcenar's Sappho is a contemporary character, a circus acrobat 'comme aux temps antiques elle était poétesse, parce que la forme particulière de ses poumons l'oblige à choisir un métier qui s'exerce à mi-ciel', and belongs to 'ce group de fantômes en vogue qui planent sur le villes grises. Créature aimantée, trop ailée pur le soil, trop charnelle pour le ciel.' As noted by DeJean ((1989) 295-6), here Baudelaire is a crucial reference point: in the scene Le vieux saltimbanque, in his collection of prose poems Le spleen de Paris (I863), Baudelaire sees an old derelict acrobat as the figura/figure of the old 'man of letters who survived his generation, for whom he was a brilliant entertainer; of the old poet, without friends, without family, without sons, degraded by his misery and by his audience's ingratitude, ${ }^{8} 3$

Yourcenar's Sappho, just as that of Grillparzer, is trapped between two worlds, heaven and earth, but, in contrast to her Romantic incarnation, she will not have the consolation of

8o The reference here is to the anarchists Nicola Sacco and Bartolomeo Vanzetti, two Italian immigrants controversially accused and convicted in I920-I and executed in 1927 in the USA.

8I The description unavoidably evokes images such as that of John Everett Millais' Ophelia.

82 In her beautiful 1967 introduction Yourcenar evokes her Athenian conversations with young female and male friends on the subject of the civil war in Spain (and on other themes). Writing about the political situation of those years, she notes: 'il est naturel que Feux, comme tel ou tel autre livre de la même époque, contienne des ombres portées'. On Yourcenar's Sappho see e.g Gubar (1984); DeJean (I989) 294-9; Andersson (2005); Cenni (2015) $258-63$.

83 Baudelaire's Albatros too is clearly an important part of the background: a fundamental reference point on the image is Starobinski (I970) 8I-2, on the relationship between the albatross and the clown/acrobat, and 9I-5 on Le vieux saltimbanque; it is a pity that Starobinski's brilliant essay did not deal with Yourcenar's 'Sappho'. 
a final redeeming apotheosis. Her suicide itself is destined to failure. 'Mais ceux qui manquent leur vie courent aussi le risque de rater leur suicide.' The acrobat's fall is intercepted by the machineries of the circus. 'Étourdie, mais intacte, le choc rejette l'inutile suicidée vers les filets où se déprennent des écumes de lumière; les mailles ploient sans céder sous le poids de cette statue repêchée des profondeurs du ciel. Et bientôt les manœuvres n'auront plus qu'à haler sur les sable ce corps de marbre pâle, ruisselant de sueur comme un noyée d'eau de mer.' Not an apotheosis, but not even a corpse: a statue condemned to go on living. ${ }^{84}$

\title{
6. Conclusions
}

Among the texts we have examined above only one, that of Yourcenar, might have been composed in awareness of the representation of Sappho's leap in the Porta Maggiore Basilica. It is not at all inconceivable that, trained as a classicist as she was, Yourcenar might well have been familiar at least with Carcopino's monograph. It is possible that another source of influence for her would have been Strabo's passage, where, after a list of the famous and less famous characters who dived from Cape Leucas, we find the description of a local rite in which the leap involves real scapegoats (Io.2.9):

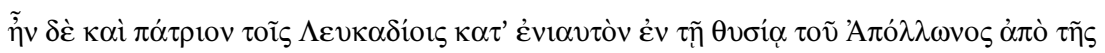

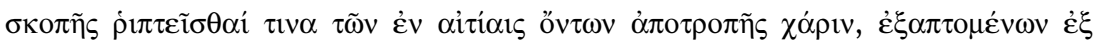

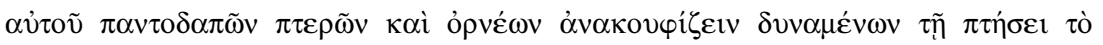

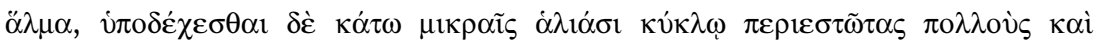

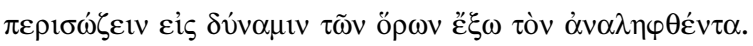

It was an ancestral custom among the Leucadians, every year at the sacrifice performed in honour of Apollo, for some criminal to be flung from this rocky lookout for the sake of averting evil, wings and birds of all kind being fastened to him, since by their fluttering they could lighten the leap, and also for a number of men, stationed all round below the rock in small fishing boats, to take the victim in, and, when he had been taken on board, to do all in their power to get him safely outside their borders. ${ }^{85}$

Just as the 'victims' in Strabo's rite face the leap tying to themselves wings and birds, so Yourcenar's acrobat is 'drapée de longs peignoirs qui lui restituent ses ailes' and keeps in her chests 'de débris d'oiseaux'. And, just as the indicted individuals forced to jump in

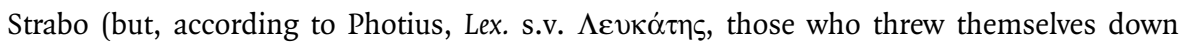
from the Rock were actually priests, iepeĩs; Servius on Aen. 3.279 uses the expression se

84 On the motif of the living statue in Yourcenar see Massimilla (20r6b).

85 Translation from Jones (I928). 
auctorare suggesting the activity of individuals who would endanger their life for a wage, just as gladiators, or acrobats), ${ }^{86}$ Yourcenar's Sappho is eventually rescued as a drowned body, but her destiny is unavoidably to go on living, as a pariah/outsider, 'beyond borders' ( $\tau \tilde{\omega} \mathrm{v}$

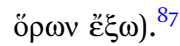

Several of the options we have examined derive from the necessity to find narratological solutions to events developed around an iconic character who is the object of continuous reshaping, in ways that are sometimes close to stereotypes, but often reveal previously unsuspected potentialities. This has been Sappho's destiny since even before there was an 'edition' of her songs. This urge to reimagine Sappho's 'afterlife' opened the path, in antiquity and beyond, to a series of visions of the poetess as harbinger of an eschatological message, or as an exemplary failure, an image variously transformed, deformed and simplified, but returning, again and again, in new creative incarnations of one of the most powerful icons of ancient Greek poetry's legacy.

\section{Works cited}

Ampolo, C. (I993) 'Il tuffo e l'oltretomba. Una nota sulla tomba del tuffatore e Plut., mor. 563 E', PP 48, I04-8.

Andersson, K. (2005) 'Sur deux visages de Sappho dans l'œuvre de Marguerite Yourcenar', in M. Ledesma Pedraz and R. Poignault (eds.), Marguerite Yourcenar. La femme, les femmes, une écriturefemme?, Clermont-Ferrand, 233-45.

Bachofen, J. J. (186I) Das Mutterrecht: eine Untersuchung über die Gynaikokratie der alten Welt nach ihrer religiösen und rechtlichen Natur, Stuttgart.

Bagordo, A. (2013) Telekleides: Einleitung, Übersetzung, Kommentar, Heidelberg.

Beaulieu, M.-C. (2016) The sea in the Greek imagination, Philadelphia.

Bendinelli, G. (I926) 'Il monumento sotterraneo di Porta Maggiore in Roma (contributo alla storia dell'arte decorativa augustea)', MonAL 3I, 602-855.

Benjamin, W. (2006) The writer of modern life: essays on Charles Baudelaire, ed. M. W. Jennings, Cambridge, $\mathrm{MA}$ and London.

Bernabé, A. (2020) 'La tomba del Tuffatore: fonti testuali', in Meriani and Zuchtriegel (2020) II-28.

Bernsdorff, H. (2020) Anacreon of Teos: testimonia and fragments, Oxford.

Bettarini, L. (2008) 'Saffo e l'aldilà in P. Köln 2135I, I-8', ZPE I65, 2I-3I.

Bianchi, F. P. (2016) Cratino. Archilochoi-Empimpramenoi (frr. 1-68), Heidelberg.

Boedeker, D. D. (1979) 'Sappho and Acheron', in G. W. Bowersock, W. Burkert and M. C. J. Putnam (eds.), Arktouros: Hellenic studies presented to B.M.W. Knox on the occasion of his 65th birthday, Berlin and New York, 40-52.

Brivitello, S. (1998) 'Saffo sulla scena', AFLB 4I, I79-205.

Brückner, T. (1989) 'Octovien de Saint-Gelais' Ovid-Übersetzung: Der Pariser Codex fr. 874 (B.N.)', Wolfenbütteler Renaissance Mitteilungen I3, 93-Ior.

Burzacchini, G. (2007) 'Saffo, il canto e l'oltretomba', RFIC I35, 37-56.

86 The texts appear as T $211 \mathrm{ra}$ in Voigt (197I), and on pp. 150-2 in Edmonds, Lyra Graeca (the reference edition for Yourcenar in that period). The passages from Strabo and Servius are mentioned (in a footnote, without full quotation) by Yourcenar herself in her introduction to Sappho in Yourcenar (1979); for an introduction to this work, and further bibliography, cf. Massimilla (2016a).

87 On the clown/acrobat as a scapegoat cf. Starobinski (1970) I32. 
Cameron, A. (2004) Greek mythography in the Roman world, Oxford and New York.

Cannatà Fera, M. (I990) Pindarus. Threnorum fragmenta (edidit M. C. F.), Rome.

Cannata Salamone, N. (2002) “Evidentia in narrazione”. Filologia e storia nell'iconografia del "Cupido", di Michelangelo e della Stanza della Segnatura', in L. Miglio and P. Supino (eds.) Segni. Per Armando Petrucci, Rome, 35-59.

Carcopino, J. (I923) 'Encore la Basilique de la "Porta Maggiore"', RA I8, I-23.

(1926) La basilique pythagoricienne de la Porte Majeure, Paris (Italian translation by G. Boni, Milan, 2020).

(1956) De Pythagore aux Apôtres. Études sur la conversion du monde romain, 2nd edn, Paris.

Ceccarelli, P. (I996) 'L'Athènes de Périclès. Un "Pays de cocagne". L'idéologie démocratique et

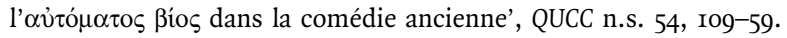

Cenni, A. (2015) “'Il salto di Saffo" dagli antichi ai contemporanei. Pavese, Yourcenar, Elytis', in Chemello (2015) 253-68.

Cerchiai, L. (2020) 'La tomba del Tuffatore e la pittura tombale degli Etruschi', in Meriani and Zuchtriegel (2020) 49-53.

Cesaro, N. (2015) 'Alcune versioni censurate dell'epistola di Saffo a Faone', in Chemello (2015) 89-113. Chemello, A. (ed.) (20I5) Saffo. Riscritture e interpretazioni dal xvi al xx secolo, Padua.

Chrysanthou, A. (2020) Defining Orphism: the beliefs, the 'teletae' and the writing, Berlin and Boston.

Coarelli, F. (I974) Guida archeologica di Roma, Verona.

Conti Bizzarro, F. (1990-3) 'Note a Ferecrate', MCr 25-8, 79-I2I.

Cowart, G. (2008) The triumph of pleasure: Louis XIV and the politics of spectacle, Chicago.

Cruciani, C. (2000) 'Il suicidio di Saffo nell'abside della Basilica Sotterranea di Porta Maggiore', Ostraka $9,165-73$.

D'Alessio, G. B. (2018) 'Poeta, personaggio e testo nell'Epistola di Saffo a Faone', MD 8I, 83-IoI.

(2020) 'Saffo nell'Oltretomba (Ferecrate, Minatori II3 e II4 K. A.)', in G. B. D’Alessio, L. Lomiento, C. Meliadò and G. Ucciardello (eds.), Il potere della parola. Studi di letteratura greca per Maria Cannatà Fera, Alessandria, II5-26.

DeJean, J. (1989) Fictions of Sappho 1546-1937, Chicago and London.

Denis, D. (200I) Le Parnasse galante. Institution d'une categorie littéraire du xuiie siècle, Paris $200 \mathrm{.}$

Densmore Curtis, C. (I920) 'Sappho and the "Leucadian Leap"', AJA 24, I46-50.

Detienne, M. (1958) 'Ulysse sur le stuc centrale de la Basilique de la Porta Maggiore', Latomus 17, 270-95.

Dieterich, A. (I893) Nekyia: Beiträge zur Erklärung der neuentdeckten Petrusapokalypse, Leipzig.

Dörrie, H. (1975) P. Ovidius Naso: Der Brief der Sappho an Phaon mit literarischem und kritischem Kommentar im Rahmen einer motiugeschichtlichen Studie, Munich.

Durrieu, P. and J.-J. Marquet de Vasselot (I894) Les manuscrits à miniatures des Hérö̈des d'Ovide, traduites par Saint-Gelais, et un grand miniaturiste français du xvie siècle, Paris.

Edmonds, R. G. (ed.) (20II) The 'Orphic' gold tablets and Greek religion: further along the path, Cambridge.

Farioli, M. (200I) Mundus alter. Utopie e distopie nella commedia greca antica, Milan.

Favaro, F. (2012) “Faoniade” di Vincenzo Maria Imperiali (1780). La Faoniade. Inni e odi di Saffo tradotti dal greco in metro italiano da S.I.P.A.', in A. Chemello (ed.), Saffo tra poesia e leggenda. Fortuna di un personaggio nei secoli XVIII e XIX, Padua, I3I-92.

Ferrari, F. (2007) Una mitra per Kleis. Saffo e il suo pubblico, Pisa.

Finglass, P. and A. Kelly (eds.) (202I) The Cambridge companion to Sappho, Cambridge.

Franchini, E. (2020) Pherekrates frr. 85-163, Göttingen.

Galbiati, G. S. (2015) 'Saffo nella traduzione delle Heroides di Remigio Nannini', in Chemello (2015) 29-42.

Gow, A. S. F. and D. L. Page (1965) Hellenistic Epigrams. Volume II: Commentary and indexes, Cambridge.

Gubar, S. (1984) 'Sapphistries', Signs Io, 43-62.

Hardie, A. (2005) 'Sappho, the Muses, and life after death', ZPE 154, 13-32.

Heinemann, A. (2020) 'Stasera mi butto. La tomba del Tuffatore e l'esperienza immersiva del simposio', in Meriani and Zuchtriegel (2020) 229-57. 
Hériché-Pradeau, S. (2020) 'La Sappho du xve siècle, de la clergesse à la poetesse amoureuse', in C. GaullierBougassas (ed.), Figures littéraires grecques en France et en Italie aux xive et xve siècles, Turnhout, I6I-77. Herrero de Jáuregui M. et al. (eds.) (20II) Tracing Orpheus: studies of Orphic fragments, Berlin and Boston. Hölscher, T. (2020) 'Troppo bello per essere reale? Per un'interpretazione sociologica e antropologica del Tuffatore', in Meriani and Zuchtriegel (2020) 499-506.

Hubaux, J. (I932) 'La "fatale" basilique de la Porta Maggiore', AntCl I, 375-94.

Hutchinson, G. O. (2020), 'Anacreon on Stage? A Note on P. Oxy. LxxxIV 54IO', ZPE 213, 4-5.

Jones, H. L. (I928) The Geography of Strabo. Volume viII, Cambridge, MA and London.

Kock, T. (I862) Alkäos und Sappho, Berlin.

Krauß, A. (2011) 'Constellations: a brief introduction', MLN I26, 439-45.

Lawergren, B. (20II) 'The rebirth of the angular harp', Early Music America 17.2, 26-3I and 57.

Lemer, J. (I850) Les poètes de l'amour. Recueil de vers français des xve, xVIe, xVIIe, xvIIIe et xixe siècles, précédé d'une introduction par M. J. L., Paris.

Leo, G. M. (2015) Anacreonte. I frammenti erotici, Quaderni di SemRom I8, Rome.

Maas, M. and J. McIntosh Snyder (I989) Stringed Instruments of Ancient Greece, New Haven and London.

Massimilla, G. (20I6a) 'Marguerite Yourcenar lettrice dei classici. Un Notturno in Denier du rêve e le traduzioni dei poeti greci in La couronne et la lyre', Eikasmos 27, 399-413.

(20I6b) 'Suggestioni classiche in Denier du rêve di Marguerite Yourcenar', in M. Capasso (ed.), Sulle orme degli Antichi. Scritti di filologia e di storia della tradizione classica offerti a Salvatore Cerasuolo, Lecce, 405-34.

Maurer, K. (2000) 'Teilnahme am Untergang einer verschmähten Liebenden: Leopardis Ultimo canto di Saffo', in C. Fischer and C. Veit (eds.), Abkehr von Schönheit und Ideal in der Liebeslyrik, Stuttgart and Weimar, 213-34.

Meautis, G. (1930) 'Sappho et Leucothéa', REA 32, 333-8.

Meriani, A. and G. Zuchtriegel (eds.) (2020) La tomba del Tuffatore. Rito, arte e poesia a Paestum e nel Mediterraneo d'epoca tardo arcaica. Atti del Convegno Internazionale, Paestum, 4-6 ottobre 2018, Pisa.

Mittelmeier, M. (2013) Adorno in Neapel: wie sich eine Sehnsuchtlandschaft in Philosophie verwandelt, Munich.

(2019) Adorno a Napoli. Un capitolo sconosciuto della filosofia europea, Milan (abridged translation of Mittelmeier (2013)).

Most, G. W. (I995) 'Reflecting Sappho', BICS 40, I5-38 (repr. in E. Greene (ed.), Re-reading Sappho: reception and transmission, Berkeley (I996) II-35).

Müller, K. O. (I840) History of the literature of ancient Greece. Volume I, London.

Murray, O. (2020) 'The Tomb of the Diver and the iconography of the Symposion', in Meriani and Zuchtriegel (2020) I97-2I4.

Mynors, R. (1963) Catalogue of the manuscripts of Balliol College Oxford, Oxford.

Nagy, G. (1973) 'Phaethon, Sappho's Phaon, and the White Rock of Leukas', HSPh 77, 137-77 (repr. in id., Greek mythology and poetics, Ithaca (I990) 223-62).

Neri, C. and F. Cinti (2017) Saffo. Poesie, frammenti e testimonianze. Introduzione e nuova traduzione e commento a c. di C. N. and F. C., Ariccia.

North, J. A. (2012) 'Sappho underground', in B. Dignas and R. R. R. Smith (eds.), Historical and religious memory in the ancient world, Oxford, 37-68.

Olson, S. D. (2017) Eupolis: testimonia and Aiges-Demoi (frr. 1-146). Introduction, translation and commentary, Heidelberg.

Olson, S. D and R. Seaberg (2018) Kratinos frr. 299-514: translation and commentary. Heidelberg.

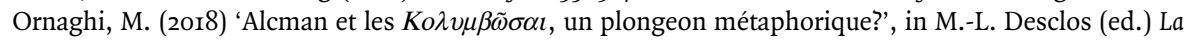
poésie archaïque comme discours de savoir, Paris, I43-73.

Pagani, L. (2006) 'Ptolemaeus [4] Chennus', in Lexicon of Greek grammarians of antiquity, online at: http://dx. doi.org/Io.II63/245I-9278_Ptolemaeus_4_Chennos_it.

Palmisciano, R. (1998) 'Lamento funebre, culto delle Muse e attese escatologiche in Saffo (con una verifica su Archiloco)', SemRom I, I83-205. 
(20I7) Dialoghi per voce sola. La cultura del lamento funebre nella Grecia antica, Quaderni di SemRom 22, Rome.

Pellegrino, M. (2000) Utopie e immagini gastronomiche nei frammenti dell'Archaia, Bologna.

(2013) Nicofonte. Introduzione, traduzione e commento, Heidelberg.

Petrides, A. K. (202I) 'Menander's Leukadia: a re-examination of the fragments and a new chapter in the play' s modern reception', in V. Mastellari (ed.), Fragments in Context - Frammenti e dintorni, Göttingen, I63-87.

Piantanida, C. (202I) 'Early modern and modern German, Italian, and Spanish Sapphos', in Finglass and Kelly (202I) 343-6o.

Pichois, C. (1975) Baudelaire. Euvres complètes. Texte établi, présenté et annoté par C. P. Volume I, Paris.

Pirrotta, S. (2009) Plato comicus: die fragmentarischen Komödien. Ein Kommentar, Berlin.

Pollock-Renck, A. (2019) 'Les Héroïdes à la fin du Moyen Âge: pour une définition élargie de l'acte traducteur', Anabases 29, 239-53.

Rehrenböck, G. (I985) 'Pherekrates-Studien', PhD thesis, University of Vienna.

(I987) 'Das Schlaraffenland im Tartaros: zur Thematik der Metalles des Komikers Pherekrates', Wiener Humanistische Blätter 29, I4-25.

Rohde, E. (I903) Psyche: Seelencult und Unsterblichkeitsglaube der Griechen. Volume I, Leipzig.

Rosati, G. (1996) 'Sabinus, the Heroides and the poet-nightingale: some observations on the authenticity of the Epistula Sapphus', CQ 46, 207-I6.

Ross Holloway, R. (2006) 'The Tomb of the Diver', AJA IIo, 365-88.

Rutherford, I. (2015) 'Stesichorus the romantic', in P. J. Finglass and A. Kelly (eds.), Stesichorus in context, Oxford, 98-Io8.

Sauron, G. (I994) Quis deum? L'expression plastique des idéologies politiques et religieuses à Rome, Rome.

Saxl, F. and H. Meier (1953) Catalogue of astrological and mythological illuminated manuscripts of the Latin Middle Ages. Volume III: Manuscripts in English libraries, ed. H. Bober, London.

Starobinski, J. (1970) Portrait de l'artiste en saltimbanque, Geneva.

Stein, J. E. (I98I) 'The iconography of Sappho: 1775-I885', PhD thesis, University of Pennsylvania.

Strong, E. and N. Jolliffe (I924) 'The stuccoes of the underground Basilica near the Porta Maggiore', JHS $44,65-$ III.

Tagliacozzo, T. (2018) Experience and infinite task: knowledge, language, and messianism in the philosophy of Walter Benjamin, Lanham.

Taufer, M. (2010) Il mito di Tespesio nel De sera numinis vindicta di Plutarco, Naples.

Telò, M. (2007) Eupolidis Demi, Florence.

Terzēs, C. (2013) 'The Daphnē harp', Greek and Roman Musical Studies I, I23-49.

Tosi, R. (I998) 'Appunti sulla filologia di Eratostene di Cirene', Eikasmos 9, 327-46.

Urios-Aparisi, E. (I992) 'The fragments of Pherecrates', PhD thesis, University of Glasgow.

Vendries, C. (I999) Instruments à cordes et musiciens dans l'empire romain. Étude historique et archéologique (IIe siècle av. J.-C./ve siècle ap. J.-C.), Paris and Montreal.

Voigt, E.-M. (I97I) Sappho et Alcaeus. Fragmenta, Amsterdam.

Waern, I. (I972) 'Flora Sapphica', Eranos 70, I-II.

Welcker, F. G. (I8I6), Sappho von einem herrschenden Vorurtheil befreyt, Göttingen. (= Kleine Schriften zur griechischen Litteraturgeschichte. Volume II (Bonn, I845) 80-I29).

West, M. L. (I992) Ancient Greek music, Oxford.

Wilamowitz-Moellendorff, U. (I9I3) Sappho und Simonides: Untersuchungen über griechische Lyriker, Berlin.

Wordsworth, C. (I844) Theocritus. Codicum manuscriptorum ope recensuit et emendavit Ch. W., Cambridge.

Yatromanolakis, D. (2007) Sappho in the making, Washington, DC.

Yourcenar, M. (1936) Feux, Paris (revised edn, with I967 introduction: Paris 1968).

(I979) La couronne et la lyre, Paris. 